\title{
Halkla İlişkiler Faaliyetleri Kapsamında Sosyal Sorumluluk Projelerinin Kurumsal Markalaşmaya Etkisi: "Domestos Okullarda Hijyen” Kampanya Örneği
}

\section{The Effect of Social Responsibility Projects on Corporate Branding in The Scope of Public Relations Activities: The Example of Domestos Hygiene Campaign in Schools}

\author{
Şeyhmus Doğan, ${ }^{a}$ Duygu Ünalan ${ }^{\text {b,* }}$ \\ ${ }^{a}$ Dr. Öğr. Üyesi, Niğde Ömer Halisdemir Üniversitesi, İletişim Fakültesi, Halkla İlişkiler ve Reklamcılık Bölümü, 51240, Niğde/Türkiye. \\ ORCID:0000-0002-5993-0363
}

b Dr. Öğr. Üyesi, Niğde Ömer Halisdemir Üniversitesi, İletişim Fakültesi, Gazetecilik Bölümü, 51240, Niğde/Türkiye. ORCID: 0000-0002-7420-2006

\section{MAKALE BİLGISII}

\section{Makale Geçmişi:}

Başvuru tarihi: 22 Ekim 2019

Düzeltme tarihi: 21 Şubat 2020

Kabul tarihi: 05 Mart 2020

\section{Anahtar Kelimeler:}

Halkla ilişkiler,

Kurumsal İletişim,

Kurumsal Sosyal Sorumluluk
ÖZ

Bu çalışmada; halkla ilişkiler ve sosyal sorumluluk uygulamaları ilişkisinin marka imajına katkısının nasıl olduğu Domestos markasının "Okullarda Hijyen" kampanyasının hedef tüketici/müşteri grubunda meydana getirdiği algı, tutum ve davranış değişiklikleri üzerinden belirlenmeye çalışılmıştır. Bu bağlamda 150 kişilik bir çalışma grubuna anket uygulanmıştır. Katılımcıların yaş, gelir ve cinsiyete göre dağılımını belirlemek amacıyla öncelikle çapraz tablolar alınmıştır. Katılımcıların kampanyaya bakış açısını ölçmeye yönelik hazırlanan sorulara verdikleri yanıtların dağılımını görmek amacıyla frekans analizi, bağımsız değişkenlere göre farklılık olup olmadığını belirlemek amacıyla da ki kare testi yapılmıştır. Elde edilen veriler sonucunda katılımciların sosyal sorumluluk projelerine önem verdikleri, marka tercihlerinde sosyal sorumluluk projelerinin etkili olduğu ve sosyal sorumluluk projelerinin marka imajına olumlu katkı sağladığı sonucuna varılmıştır.

\section{ARTICLE INFO}

Article history:

Received 22 October 2019

Received in revised form 21 February 2020

Accepted 05 March 2020

\section{Keywords:}

Public Relations,

Corporate Communications,

Corporate Social Responsibility

\section{A B S T R A C T}

In this study, it has been tried to determine the contribution of public relations and social responsibility practices to the brand image through the perception, attitude and behavior changes created by the Hygiene in Domestos Schools campaign in the target consumer/customer group. In this context, a survey was applied to a working group of 150 people. Frequency analysis was conducted to see the distribution of the responses of the participants to the questions prepared to measure the perspective of the campaign, and chi-square test was used to determine whether there were differences according to the independent variables. As a result of the data obtained, it was concluded that the participants attach importance to social responsibility projects, social responsibility projects are effective in brand choices and social responsibility projects contribute positively to the brand image.

\section{Giriş}

Değişen rekabet anlayışıyla beraber markalar, kurumsal sosyal sorumluluk projeleri ile müşterilerinin ve hedef gruplarının duygusal beklentilerini karşılayarak kurumsal marka algılarını olumlu şekilde yansıtmaya çalışmaktadır. Günümüz müşteri profili özellikle çevreye ve toplumsal sorunlara karşı duyarlı olan sosyal sorumluluk bilincine sahip işletmeleri tercih etmektedir. Değişen müşteri beklentileri doğrultusunda işletmelerin çoğu toplum, çevre ve tüketici çıkarlarını gözeterek faaliyetlerini devam ettirmeye çalışmaktadır.

Her ne kadar halkla ilişkiler alanının tarihi 20. yüzyılın başlarına dayanıyor olsa da alanın önem ve sorumluluğunun artışı 1970'li yılların sonuna denk gelmektedir. Bu dönemden önce, halkla ilişkiler alanında ürün ya da firmayla ilgili bilginin yayılmasına ve yayılan bilginin kalitesine önem verilirdi; ancak mesajların alıcısı konumundaki hedef kitle ya da paydaşların geri

\footnotetext{
* Sorumlu yazar/Corresponding author

e-posta: duyguunalan85@gmail.com
} 
bildirimlerinin henüz tam olarak göz önünde bulundurulmadığı bir yapı söz konusuydu. 1970’li yılların sonu ve 1980'li yılların başından itibaren iş dünyasında ve toplumdaki önemli değişimlerin halkla ilişkileri de iletişim alanının merkezine koyarak etkilediği görülmektedir. Paydaşlarla sosyal ilişkileri geliştirme fikrinin yükselişi, imaj ve itibar oluşturup geliştirme, ilişki yönetimi ve markalaşma gibi kavramlara odaklanma halkla ilişkiler alanında bu dönemde söz konusu olmuştur.

Günümüzde artık bir işletmenin tüm çevresinden sorumlu bir aktör olduğu ve sosyal taleplere, sorunlara veya baskılara cevap vermesi gerektiği; iş süreçleri ile ilgili sosyal sorunlara (duyarlılık) ve etik davranış olarak kabul edilen yaklaşımlara nasıl cevap verme eğiliminde olduklarından sorumlu oldukları fikrine dayandırılmış kurumsal sosyal sorumluluk modelleri yaygınlaşmaya başlamıştır. İşletmeler ve markaların toplumsal ihtiyaçlara ve baskılara cevap verme sorumluluğuna dayanan halkla ilişkiler tabanlı sosyal sorumluluk projeleri de marka ile hedef kitle arasında güçlü bir bağın geliştirilmesini sağlamaya yönelik faaliyetlerdir. İlişki bağının güçlenmesiyle markaların var olan ve potansiyel durumdaki müşteri grupları ve diğer tüm paydaşları ile iletişiminin sürekliliği de kolaylaşmaktadır. Bu etkili iletişim sürecinin marka imajına ve marka itibarına doğrudan etki edeceği düşünülmektedir. Bu bağlamda bu çalışmada Domestos markası örneğinde sosyal sorumluluk projelerinin marka imajına katkısı olup olmadığının ortaya koyulması amaçlanmıştır.

\section{Kavramsal Çerçeve: Halkla İliş̧kiler, Kurumsal Sosyal Sorumluluk ve Markalaşma}

Halkla ilişkiler, kurumsal iletişim ve kurumsal sosyal sorumluluk kavramlarının kökenleri ile organizasyonel işlev ve sorumlulukları literatürden yola çıkılarak değerlendirildiğinde; organizasyonel süreçler bakımından hem mantık olarak hem de kurumsal hedefler olarak iç içe olan bir yapıya sahip kavramlar oldukları görülmektedir. Söz konusu kavramlar en temelde kurumsal ya da ürünsel markalaşma amacına hizmet etmektedir.

Kurumsal sosyal sorumluluk (kss) projeleri; çeşitli alanlarda etik ve sosyal açıdan sorumlu eylem alanları geliştirmek için çeşitli paydaşlarla şeffaf ve açık diyalogların kurulmasında ve sürdürülmesinde halkla ilişkiler ve kurumsal iletişimin rolünü vurgulamaktadır (Kirat, 2015: 440; Golob ve Bartlett, 2007: 2). Kurumsal iletişim süreçlerinin kurumsal sosyal sorumluluk alanındaki etkisinin/başarısının artan önemi, halkla ilişkiler uygulayıcılarının kurumsal iletişimdeki başarılarını artırmış ve kurumsal imajı geliştirme ve yönetme konusundaki görevini destekler bir anlayış ve yapı sağlamıştır.

Kurumsal sosyal sorumluluk (kss) projelerinin yükselişi, şirket ya da markaların imajı için artan endişelerin daha fazla önemsendiği 1970'lerin sonu ve 1980'lerin başına denk gelmektedir. Artık şirketler için toplantı odalarının kapalı tutulamadığ 1 ve yöneticilerin sessiz kalamadığı; bunun yerine, şirketlerin halktan-hedef gruplarından gelen bilgi talebi için sürekli artan bir talebe uyum sağlamak zorunda kaldığ 1 bir döneme girilmiştir. Bu dönem genel olarak halkın da bir birincil grup/hedef kitle olarak görülmeye başlandığı bir dönemi ifade etmektedir. 1980'lerin ve 1990'ların başında ise firmalar için sosyal sorumluluk ve sosyal performans kesin bir modelden ya da üzerinde anlaşmaya varılan bir dizi kavramdan yoksundur; ancak yine de birçok teorisyen ve halkla ilişkiler uygulayıcısı kss'yi açıklamayı amaçlayan ana başlıkları belirlemiş durumdayd1 (Clark, 2000: 364).

Firma ya da markalar kurumsal sosyal sorumluluk odaklı faaliyetler yürüterek, toplumun refahına katkı sağlamak ve çevreyi korumak üzere geliştirilen sosyal konulara destek veremeye çalışırlar. Bu tür uygulamalar arasında sosyal sorumluluk kampanyaları ön plana çıkmaktadır (Kotler ve Lee, 2005:208). Firma adına yapılan bu uygulamalarla, firma ve firmanın müşterileri arasında güçlü bir ilişki kurulması amaçlanır. Kss kampanyaları, markalaşmaya hizmet etmesi hedeflenen ayırt edilebilir, taklit edilemez, tercih oluşturabilir ve bir itibar unsuru olarak sosyal paydaşlarla iletişim-ilişki köprüsü görevini üstlenen projeler olarak değerlendirilebilir.

Çevresel, politik ve sosyal ortamını değerlendirebilecek bir şirketin toplumsal taleplere daha duyarlı olması için gereken bilgiye sahip olacağı varsayımından hareketle ortaya çıkan kss kavramı (Dozier, 1990: 6) çevresel bir değerlendirmedir ve hem iç hem de dış ortamı araştırmak ve iletişimi bir değerlendirme aracı olarak kullanmaya dayanmaktadır. Halkla ilişkiler de ilişki yönetimi ve sosyal ilişkiler için önemli bir unsur olan dış ve iç paydaş ilişkileri stratejisini, üst yönetim felsefesini ve topyekün bir iç değerlendirmeyi sürece dâhil etmekte ve adeta bir birleştiricilik ortamı sağlamaya yardımcı olmaktadır.

Halkla ilişkiler, stratejik plan yapabilmeyi, planlanan faaliyet hedefleri hakkında sağlam kararlar almayı, kilit halkları tanımlamayı, politika ve iletişim stratejilerini belirlemeyi içermektedir. Bunların hepsi belirlenmiş kurumsal hedefler ve her paydaş grubunun ihtiyaçları göz önünde bulundurularak yapılmaktadır. Paydaş analizi ve yönetimi; şirket ya da markaların paydaş talep ve beklentilerini ele almaya ve paydaş içindeki kendi güç ve etki konumlarını iyileştirmeye, paydaş ortamlarını anlamaya ve paydaş ilişkilerini yönetmeye çalışılan bir süreçtir.

Halkla ilişkiler ve kurumsal sosyal sorumluluk süreçlerine bakıldığında, bu iki disiplinin ortak yanlarının çok olduğu anlaşılmaktadır. Her ikisi de birbirinin ana süreçlerini ve içeriklerini kapsamakta ve böylece neredeyse birbirini yansıtmaktadırlar. Öncelikle halkla ilişkiler; kurumsal sosyal performansın artırılması ile üst yönetimdeki sosyal konular arasındaki merkezi birleştirici bir faktördür. Yönetim sürecinin ilk aşamasından başlayarak, etkili halkla ilişkiler uygulayıcıları sorunun araştırılması ve tanımlanması veya bazı durumlarda firsatlar üzerinde yoğunlaşmaktadır (Cutlip, Center ve Broom, 1994: 323 324). Bu ilk adım, bir kuruluşun eylemleri ve politikaları ile ilgilenen veya bunlardan etkilenenlerin bilgilerini, fikirlerini, tutumlarını ve davranışlarını izlemek ve onları kurum veya marka lehine dönüştürme amacındadır. Bir nevi paydaş analizi yapılarak, yani paydaşlarla ilgili bilgi toplamak ve paydaşlar ne biliyorlar, nasıl hissediyorlar ve sorunla ilgili ne düşünüyor ve ne yapıyorlar, beklentileri nelerdir? gibi soruların cevapları bulunmaya ve kss projesi kapsamında çözümün parçası olunmaya çalışılmaktadır.

Halkla ilişkiler ve kurumsal sosyal sorumluluk kavramlarının ortak yanları şu şekilde özetlenebilir: Tüm 
sosyal paydaşların analizi, tanımlanması ve marka veya işletme tarafina çekilmesinde stratejik iletişim etkinliğine ihtiyaç söz konusudur. Her iki kavram da bir iletişim yönetimine dayanmaktadır. İletişimin paydaş iliş̧kilerinin tam kalbinde olduğu düşünülecek olursa, halkla ilişkiler ve kss'nin ilişki ve iletișim yönetimi ortaklığı daha belirgin bir şekilde ortaya çıkmaktadır.

Halkla ilişkilerin temel iddialarından biri, bir yönetim işlevi olduğudur (Grunig, 2001: 14). Stratejide ve uygulamada hem kss hem de halkla ilişkiler bir yönetim işlevi olarak değerlendirilebilir. Capriotti ve Moreno'ya (2006: 86) göre; halkla ilişkiler ve kurumsal sosyal sorumluluk bir zincirin anahtar halkaları gibidir ve kss'yi halkla ilişkilerin kalbi olarak tanımlamak gerekir; çünkü kss uygulamaları halkla ilişkilerin rolünü ve etki alanını genişletmiştir.

Kurumsal sosyal sorumluluk uygulamaları incelendiğinde; halkla ilişkiler profesyonellerinin kss faaliyetlerinden sıklıkla sorumlu olduğu görülmektedir (Goodwin ve Bartlett, 2008: 13). Bilgiyi yayma, güven oluşturma, kurumsal etik kaygı, şeffaflık ve hesap verebilirlik, paydaş katılımını artırmak, toplumsal farkındalık, toplumsal duyarlılık ve uyum, kurum imajı ve kurumsal itibar gibi diğer temaların da katılımlarıyla doğrudan bir iç içelik gösterdikleri apaçıktır; çünkü bu kavramlar kss'nin ve halkla ilişkilerin temel kurumsal aksiyon temalarıdır. $\mathrm{Bu}$ doğrultuda kss projelerini; bir kuruluş ya da markanın paydaşlar nezdinde sosyal kabulü sağlamak yoluyla imajını ve itibarını güçlendirmek için kullanabileceği, iletişim ve ilişki odaklı bir halkla ilişkiler stratejisi/faaliyeti dolayısıyla reaktif bir pazarlama iletişimi stratejisi olarak değerlendirmek yerinde olacaktır. Çünkü halkla ilişkiler, kurumsal sosyal sorumluluk uygulamaları yoluyla, sosyal paydaş diyaloğu kurmada, paydaş talepleriyle başa çıkmada ve sosyal meşruiyeti inşa etme ve korumada etkili bir faaliyet alanı elde etmektedir.

Geleneksel bir marka stratejisi, birincil paydaşlara (örneğin müşteriler, hissedarlar, iş ortakları) odaklanır (Vallaster, Lindgreen ve Maon, 2012: 35). Buna karş1l1k, halkla ilişkiler bakış açısıyla ve stratejik kurumsal iletişime dayanan bir yapıda, şirketin faaliyetlerinden etkilenen ve etkilenebilecek tüm sosyal paydaşların ele alınması gerekmektedir. Bu doğrultuda; kurumsal sosyal sorumluluk kavramı da markalaşmanın kurallarını değiştirmiştir. Sadece çok satarak, yüksek karlar açıklayarak, devasa yatırımlar yaparak değil, topluma fayda sağlayarak kurumsal bir marka olmayı zorunlu k1lan bir temele dayanmaktadır. Kss projesi yoluyla markalaşmak için ikincil paydaşların göz önünde bulundurulması gerekmektedir.

$\mathrm{Bu}$ paydaşlar, firma ya da markanın faaliyetleri açısından kesin kabul ve onayının alınması hedeflenen, markanın misyonunu destekleyecek sosyal, ekonomik ve politik aktörleri kapsamaktadır. Daha araçsal bir bakış açısıyla bu paydaşlar; şirket itibarını güçlendirecek, maddi olmayan varlıklar sağlamaya yardımcı olabilirler (Brüggenwirth, 2006: 143). Böylece kss projeleri konumlandırmaları bir marka stratejisi perspektifi olarak, ilgili tüm paydaş gruplarıyla bağlantı kuran genel bir marka değeri artışında bulunabilir.

Kurumsal sosyal sorumluluk projeleri, halkla ilişkiler alanının en önemli paydaş iletişim aracı ve uygulamalarından biri olarak, markaların ticari bir güç, taklit edilemez bir rekabet avantajı ve olumlu bir imaj-itibar elde etmek için üzerinde durulması gereken uygulamalar olarak değerlendirilmelidir.

Bir marka ya da şirketin çevresi ve toplumun çıkarları için neler yaptığı fikrine dayanan kurumsal sosyal sorumluluk kavram1, Özdemir'e (2009) göre; "küreselleşen günümüz dünyasında işletmeler açısından bir gereklilik haline gelmiştir. Toplumdan aldığını topluma geri vermek ve işletmenin faaliyetlerinde toplum yararını gözetmesi ilkelerine dayanan kurumsal sosyal sorumluluk anlayışı, işletmelerin ürettikleri ürün ve hizmetleri en iyi şartlarda pazarda tanıtmaları ve marka imajını güçlendirmeleri açısından önemli bir yere sahiptir. Rakiplerinden farklılaşmak isteyen işletmelerin marka imajlarını da farklılaştırmaları gerekmektedir. Bu açıdan bakıldığında kurumsal sosyal sorumluluk, farklılık yaratmak için geçerli bir uygulama olarak görülmektedir. Bir marka, toplumsal sorunlara getirdiği çözümler ile marka imajını geliştirebilmekte ve ürettiği ürün ve hizmetlere kattığı ek değer sayesinde benzerleri arasında fark edilebilir hale gelmekte ve daha fazla tercih edilebilir olmaktadır" (s.57). $\mathrm{Bu}$ doğrultuda; halkla ilişkiler perspektifli sosyal sorumluluk çalışmalarının başarısı, marka ile hedef kitleleri arasında güçlü bir bağın geliştirilmesine bağlıdır. Bu bağ, duygusal bir bağ olmalı ve değer temelli bir iletişim stratejisine dayanmalıdır. Bu sayede markaların var olan ve potansiyel durumdaki müşteri grupları ile iletişim kurması da kolaylaşmaktadır. $\mathrm{Bu}$ etkili iletişim sürecinin de markalaşmaya, marka imajına ve marka itibarına doğrudan etki edeceği düşünülmektedir.

\section{Domestos "Okullara Domestos Bağışı Hijyen Kampanyası"}

Domestos temizlik ürünleri satan bir markadır. Yaptığı kurumsal sosyal sorumluluk çalışmalarıyla çocukların sağlıklı şartlarda okuması ve çocuklarda hijyen bilinci oluşturma amacındadır ve Türkiye'de hijyen platformunu yaratmayı hedeflemektedir. 2011 yılından bu yana, Türk Eğitim Gönülleri Vakfı (TEGV) işbirliğiyle 'Eğlen, Öğren, Hijyen' projesi kapsamında çocuklara hijyen eğitimi vermeye devam etmektedir. Süreç içerisinde bu çalışma; okullara temizlik katkısı "Okullara Domestos Bağıșı ve Hijyen Kampanyası” sosyal sorumluluk çalışmasına dönüşmüştür.

Domestos, bu sosyal sorumluluk çalışmasını "Domestos Alın, Okullara Domestos Bağışına Destek Olun"” sloganı ile yürütmektedir". Sosyal medyada kampanyaya dikkat çekmek ve geniş bir hedef kitleye ulaşmak amacıyla; sosyal sorumluluk kampanyası tanıtımı odaklı "\#mikroplarisyanda" etiketiyle projeyi tanıtan reklam çalışmaları da gerçekleştirmiştir. Domestos markası, 30 Mart 2018 tarihinde yayınladığı verilerde, "Okullara Domestos Bağışı ve Hijyen Kampanyası" sosyal sorumluluk projesi ile Mart 2016'dan itibaren 18 şehirde 3.684.368 öğrenciye ulaştığını belirtmiştir. ${ }^{1}$

\begin{tabular}{|c|c|}
\hline${ }^{1}$ Okullara Domestos & \\
\hline $\begin{array}{l}\text { http://www.domestoshijyenprojesi.com } \\
\text { 17.09.2018). }\end{array}$ & (Erişim \\
\hline
\end{tabular}




\section{Yöntem}

$\mathrm{Bu}$ çalışma marka konumlandırmada sosyal sorumluluk kampanyalarının etkisini belirlemeye yöneliktir. Bu amaçla gerçekleştirilen araştırmada; "Sosyal sorumluluk projelerinin marka imajına katkısı var mıdır?" sorusuna cevap aranmıştır. Bu bağlamda araştırmanın amacına uygun olarak hazırlanmış anket formu veri toplama aracı olarak kullanılmıştır. Bir veri toplama aracı olarak anket, katılımcıların belirli bir konuda düşünce, tutum ve davranışlarını daha önce belirlenmiş bir sırada ve yapıda oluşturulmuş sorulara dayalı olarak elde etmeyi sağlamaktadır. Anket yoluyla elde edilen veriyi istastiksel ve matematiksel analizden geçirmek mümkündür. Bununla birlikte anket çok sayıda kişiye ulaşılması gerektiğinde ideal bir veri toplama aracıdır (Gürbüz ve Şahin, 2016: 179).

Domestos markası örneğinde sosyal sorumluluk projelerinin marka imajına katkısı olup olmadığının ortaya koyulmasının amaçlandığı bu çalışmada 11.04.2018 ile 25.04.2018 tarihleri arasında 150 kişilik çalışma grubuna anket uygulanmıştır. Söz konusu grup velilerden oluşmaktadır. Çalışma, 150 kişilik çalışma grubu ile sinırlıdır, bu nedenle evrene genelleme niteliği bulunmamaktadır. Ankete katılım gönüllülük esasına dayanmaktadır. Araştırma anketi 22 sorudan oluşmaktadır. Anket formu kapsam ve görünüş geçerliliğini sağlamak amacıyla İktisadi ve İdari Bilimler Fakültesi ile İletişim Fakültesi'nden birer uzmanın görüşü alınarak hazırlanmıştır. Araştırmada kullanılan anket formu kapalı uçlu ve derecelendirmeli sorulardan oluşan 3 bölüm olarak hazırlanmıştır. İlk bölümde 3 soru ile ankete katılanların demografik özelliklerini belirlemeye yönelik sorular sorulmuştur. İkinci bölümde 4 adet iki seçenekli (evet/hayır) soruda katılımcıların sosyal sorumluluk projelerine bakış açılarını ölçmeye yönelik ifadeler yer almıştır. Üçüncü bölümde 15 soruluk 5'li Likert ölçeği ile oluşturulmuş sorular işletmenin sosyal sorumluluk kapsamında değerlendirilen kampanyasına yönelik ifadelerden oluşmuştur.

Anket sonucunda elde edilen veriler SPSS 24.0 İstatistik Programında sayısallaştırılmıştır. Katılımcıların yaş, gelir ve cinsiyete göre dağılımını belirlemek amacıyla öncelikle çapraz tablolar alınmıştır. Yaş grupları ve gelir düzeyine göre kadın ve erkeklerin dağılımı ayrı tablolarda verilmiştir. Katılımcıların kampanyaya bakış açısını ölçmeye yönelik hazırlanan evet/hayır sorularında öncelikle evet ve hayır dağılımını görmek amacıyla frekans analizi bağımsız değişkenlere göre farklılık olup olmadığını belirlemek amacıyla da ki kare testi yapılmıştır. 15 soruluk 5'li Likert ölçeği sorularında da her bir soru için ayrı ayrı frekans analizi, bağımsız değişkenler arasında anlamlı fark olup olmadığını görmek için de yine ki kare testi yapılmıştır. Elde edilen veriler tablolaştırılarak değerlendirilmiştir. Her bir madde için ayrı ayrı yapılan ki kare testi sonuçlarına ilişkin Chi-Square, Df ve Asymp. Sig değerleri dikkate alınarak değişkenler arasında anlamlı fark olup olmadığına bakılmıştır. Söz konusu değerler her bir madde için tabloların altında belirtilmiştir. $\mathrm{Bu}$ bağlamda öncelikle demografik verilerin sonuçları, sonrasında evet/hayır sorularına ilişkin analizler, son olarak da Likert ölçeği analiz sonuçları verilmiştir.

\section{Bulgular ve Yorumlar}

Çalışmanın bu bölümünde öncelikle katılımcıların demografik verilerine ilişkin bilgiler verilmiş, sonrasında ise katılımcıların sosyal sorumluluk projelerine bakış açılarını ölçmeye yönelik olarak sorulan evet/hayır sorularına verdikleri yanıtlar değerlendirilmiş, son olarak da katılımcıların Domestos' un Okullara Bağış Kampanyası Projesini Ölçmeye Yönelik İfadelere katılımlarını ölçmeye yönelik olarak yapılan 5'li Likert tipi ölçeğin sonuçlarına yer verilmiştir. Anket maddelerinin iç tutarlılık güvenilirliğini ölçmek amacıyla yapılan güvenilirlik analizi sonucunda güvenilirlik katsayısı 0,833 çıkmıştır. Bu oran .70'in üzerindedir. Bu sonuçlar anketin iç güvenilirliğinin yüksek olduğunu göstermektedir.

\subsection{Demografik Bilgiler}

Tablo 1. Cinsiyet ve Yaş Grupları

\begin{tabular}{ccccccc}
\cline { 3 - 7 } & & \multicolumn{5}{c}{ Yass } \\
\cline { 3 - 7 } & $25-35$ & $\%$ & $35-45$ & $\%$ & Toplam \\
\hline \multirow{2}{*}{ Cinsiyet } & Kadın & 45 & 30 & 51 & 34 & 96 \\
\cline { 2 - 7 } & Erkek & 30 & 20 & 24 & 16 & 54 \\
\hline \multicolumn{2}{c}{ Toplam } & 75 & 50 & 75 & 50 & 150 \\
\hline
\end{tabular}

Ankete katılan velilerin \%64'ünü kadınlar, \%36'sını erkekler oluşturmaktadır. Kadınların \%30’u 25-35 yaş, \%34'ü ise 35-45 yaş aralığındadır. Erkeklerin ise \%30'u 25-35, \%16'sı 35-45 yaş aralığındadır.

Tablo 2. Aylık Gelir / Harcama Grupları

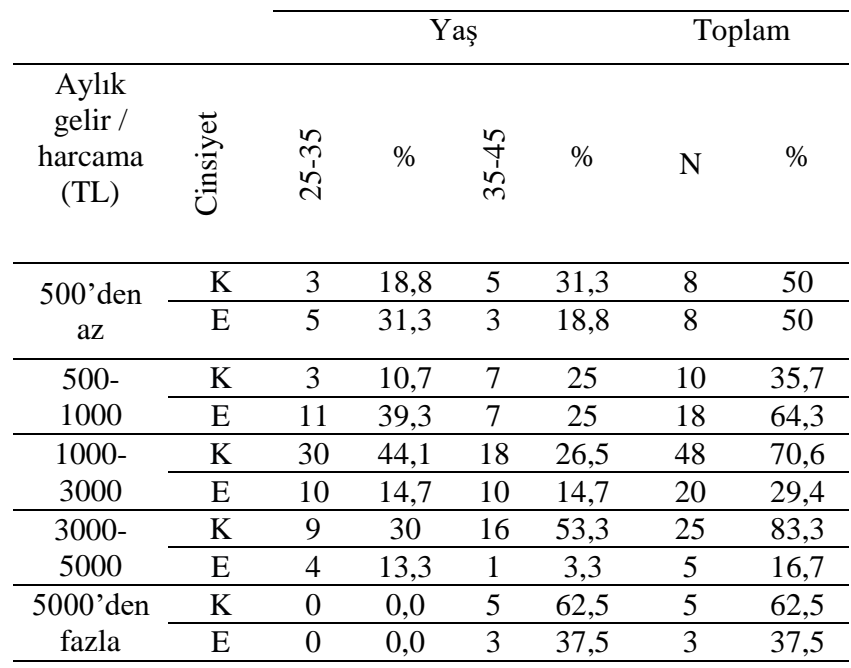

Katılımcıların aylık gelir/harcama durumlarının cinsiyet ve yaşa göre dağılımlarına bakıldığında 500 TL'den az geliri olan 8 kadının \%18,8'inin 25-25, \%31,3'ünün ise 35-45 yaş aralığında olduğu görülmektedir. Aylık geliri 500 TL'den az olan 8 erkekten 5'i (\%31,3), 25-35 yaş aralığında iken 3'ü (\%18,8) 35-45 yaş aralığındadır. Aylık geliri 500-1000 TL arasında olan kadınların 3'ü \%10,7) 25-35, 7'si (\%25) ise 35-45 yaş aralığındadır. Aylık geliri 500-1000 TL arasında olan 18 erkekten 11 'i $25-35,7$ 'si ise 35-45 yaş aralığındadır. Geliri 1000-3000 arasında olan 48 kadın 20 erkek olduğu görülmektedir. Kadınların \%44,1'i 25-35, $\% 26,5$ 'i ise 35-45 yaş aralığındadır. Erkeklerde ise yaş aralıklarında eşit dağılım görülmektedir. İki yaş aralığında da 10'ar katılımeı bulunmaktadır. Geliri 3000-5000 aralığında olan kadınların \%30'u (9 kişi) 25-35, \%53,3'ü (16 kişi) ise 35-45; erkeklerin \%13,3'ü (4 kişi) 25-35, $\% \% 3,3$ 'ü (1 kişi) 35-45 yaş aralığındadır. Aylık geliri 
5000 'den fazla olan 5 kadın ve 3 erkeğin ise tamamı 35-45 yaş aralığındadır.

5.2. Katılımciların Sosyal Sorumluluk Projelerine Bakış Açılarını Ölçmeye Yönelik İfadeler

$\mathrm{Bu}$ bölümde katılımcıların sosyal sorumluluk projelerine bakış açılarını ölçmeye yönelik sorulara verdikleri yanıtların analizlerine yer verilmiştir.

Tablo 3. Sosyal Sorumluluk Projelerine Önem Verir Misiniz? Sorusuna Verilen Yanıtların Dağılımı

\begin{tabular}{|c|c|c|c|c|c|c|}
\hline \multirow{2}{*}{$\begin{array}{l}\text { Gelir } \\
\text { (TL) }\end{array}$} & \multirow{2}{*}{$\dot{\Xi}$} & \multirow{2}{*}{ Yaş } & \multicolumn{2}{|c|}{ Evet } & \multicolumn{2}{|c|}{ Hayır } \\
\hline & & & $\mathrm{N}$ & $\%$ & $\mathrm{~N}$ & $\%$ \\
\hline \multirow{4}{*}{$\begin{array}{c}500 \\
\text { den az }\end{array}$} & \multirow{2}{*}{ K } & $25-35$ & 3 & 100,0 & 0 & 0,0 \\
\hline & & $35-45$ & 5 & 100,0 & 0 & 0,0 \\
\hline & \multirow{2}{*}{$\mathrm{E}$} & 25-35 & 5 & 100,0 & 0 & 0,0 \\
\hline & & $35-45$ & 3 & 100,0 & 0 & 0,0 \\
\hline \multirow{4}{*}{$\begin{array}{l}500- \\
1000\end{array}$} & \multirow{2}{*}{ K } & $25-35$ & 3 & 100,0 & 0 & 0,0 \\
\hline & & $35-45$ & 7 & 100,0 & 0 & 0,0 \\
\hline & \multirow{2}{*}{ E } & $25-35$ & 11 & 100,0 & 0 & 0,0 \\
\hline & & $35-45$ & 6 & 85,7 & 1 & 14,3 \\
\hline \multirow{4}{*}{$\begin{array}{l}1000- \\
3000\end{array}$} & \multirow{2}{*}{ K } & $25-35$ & 29 & 96,7 & 1 & 3,3 \\
\hline & & $35-45$ & 15 & 83,3 & 3 & 16,7 \\
\hline & \multirow{2}{*}{ E } & $25-35$ & 10 & 100,0 & 0 & 0,0 \\
\hline & & $35-45$ & 10 & 100,0 & 0 & 0,0 \\
\hline \multirow{4}{*}{$\begin{array}{c}3000- \\
5000\end{array}$} & \multirow{2}{*}{ K } & $25-35$ & 8 & 88,9 & 1 & 11,1 \\
\hline & & $35-45$ & 15 & 93,8 & 1 & 6,3 \\
\hline & \multirow{2}{*}{$\mathrm{E}$} & $25-35$ & 3 & 75,0 & 1 & 25,0 \\
\hline & & $35-45$ & 1 & 100,0 & 0 & 0,0 \\
\hline \multirow{4}{*}{$\begin{array}{l}5000 \\
\text { 'den } \\
\text { fazla }\end{array}$} & \multirow[b]{2}{*}{ K } & $25-35$ & 0 & 0,0 & 0 & 0,0 \\
\hline & & $35-45$ & 4 & 80,0 & 1 & 20,0 \\
\hline & \multirow{2}{*}{$\mathrm{E}$} & $25-35$ & 0 & 0,0 & 0 & 0,0 \\
\hline & & $35-45$ & 2 & 66,7 & 1 & 33,3 \\
\hline
\end{tabular}

$\mathrm{X}^{2(1)=}, 167^{\mathrm{a}} ; \mathrm{p}>.05$

Genel olarak bakıldığında 25-35 yaş aralığındaki toplam 43 kadın sosyal sorumluluk projelerine önem verdiğini, 2 kadın ise önem vermediğini belirtmiştir. Aynı yaş aralığındaki 29 erkek evet, 1 erkek ise hayır yanıtını vermiştir. 35-45 yaş aralığına bakıldığında ise toplam 46 kadın evet yanıtını verirken 5 kadın hayır cevabını vermiştir. Erkeklerde ise 22 kişi evet, 2 kişi ise hayır cevabını vermiştir. Gelir ve yaş değişkenleri bazında kadın ve erkekler arasında anlamlı bir fark olup olmadığına bakılan ki-kare testi sonuçlarına göre p: ,682 çıkmıştır. Dolayısıyla 0,05 'ten büyüktür. Bu sonuç gelir dağılımı ve yaşa göre kadınlar ve erkekler arasında sosyal sorumluluk projelerine önem verme açısından anlamlı bir farklılık olmadığını göstermektedir.

Tablo 4. Marka Tercihinde Sosyal Sorumluluk Projeleri Etkili Midir? Sorusuna Verilen Yanıtların Dağılımı

\begin{tabular}{|c|c|c|c|c|c|c|}
\hline \multirow{2}{*}{$\begin{array}{l}\text { Gelir } \\
\text { (TL) }\end{array}$} & \multirow{2}{*}{$\dot{\Xi}$} & \multirow{2}{*}{ Yaş } & \multicolumn{2}{|c|}{ Evet } & \multicolumn{2}{|c|}{ Hayır } \\
\hline & & & $\mathrm{N}$ & $\%$ & $\mathrm{~N}$ & $\%$ \\
\hline \multirow{4}{*}{$\begin{array}{c}500 \\
\text { den az }\end{array}$} & \multirow{2}{*}{ K } & $25-35$ & 1 & 33,3 & 2 & 66,7 \\
\hline & & $35-45$ & 4 & 80,0 & 1 & 20,0 \\
\hline & \multirow{2}{*}{ E } & $25-35$ & 3 & 60,0 & 2 & 40,0 \\
\hline & & $35-45$ & 1 & 33,3 & 2 & 66,7 \\
\hline \multirow{4}{*}{$\begin{array}{l}500- \\
1000\end{array}$} & \multirow{2}{*}{ K } & $25-35$ & 2 & 66,7 & 1 & 33,3 \\
\hline & & $35-45$ & 5 & 71,4 & 2 & 28,6 \\
\hline & \multirow[b]{2}{*}{$\mathrm{E}$} & $25-35$ & 6 & 54,5 & 5 & 45,5 \\
\hline & & $35-45$ & 6 & 85,7 & 1 & 14,3 \\
\hline $1000-$ & K & $25-35$ & 21 & 70,0 & 9 & 30,0 \\
\hline
\end{tabular}

\begin{tabular}{|c|c|c|c|c|c|c|}
\hline \multirow[t]{3}{*}{3000} & & $35-45$ & 12 & 66,7 & 6 & 33,3 \\
\hline & \multirow{2}{*}{$\mathrm{E}$} & $25-35$ & 8 & 80,0 & 2 & 20,0 \\
\hline & & $35-45$ & 5 & 50,0 & 5 & 50,0 \\
\hline \multirow{4}{*}{$\begin{array}{l}3000- \\
5000\end{array}$} & \multirow{2}{*}{ K } & $25-35$ & 6 & 66,7 & 3 & 33,3 \\
\hline & & $35-45$ & 15 & 93,8 & 1 & 6,3 \\
\hline & \multirow{2}{*}{$\mathrm{E}$} & $25-35$ & 3 & 75,0 & 1 & 25,0 \\
\hline & & $35-45$ & 1 & 100,0 & 0 & 0,0 \\
\hline \multirow{4}{*}{$\begin{array}{l}5000 \\
\text { 'den } \\
\text { fazla }\end{array}$} & \multirow{2}{*}{ K } & $25-35$ & 0 & 0,0 & 0 & 0,0 \\
\hline & & $35-45$ & 4 & 80,0 & 1 & 20,0 \\
\hline & \multirow{2}{*}{ E } & $25-35$ & 0 & 0,0 & 0 & 0,0 \\
\hline & & $35-45$ & 2 & 66,7 & 1 & 33,3 \\
\hline
\end{tabular}

$\mathrm{X}^{2(1)=} 1,080^{\mathrm{a}} ; \mathrm{p}<.05$

Marka tercihlerinde sosyal sorumluluk projeleri etkili midir? sorusuna verilen yanıtlara bakıldığında 25-35 yaş aralığında toplam 30 kadının evet, 15 kadının ise hayır, 3545 yaş aralığında ise toplam 40 kadının evet, 11 'inin ise hayır yanıtını verdiği görülmektedir. Erkek katılımcılarda ise 25-35 yaş aralığında 20 evet, 10 hayır; 35-45 yaş aralığında ise 15 evet, 9 hayır yanıtı bulunmaktadır. Bununla birlikte marka tercihinde sosyal sorumluluk projelerinin etkililiğine ilişkin gelir ve yaş dağılımı değişkenleri bazında kadın ve erkek katılımcılar arasında anlamlı bir fark olduğu (p: ,299) sonucuna varılmıştır. Toplamda 70 kadın evet yanıtını verirken 35 erkek evet yanıtını vermiştir. Bu durumu kadınların sosyal sorumluluk projelerine daha duyarlı oldukları yönünde yorumlamak mümkündür.

Tablo 5. Sosyal Sorumluluk Projeleri Marka İmajını Etkiler Mi? Sorusuna Verilen Yanitların Dağıllımı

\begin{tabular}{|c|c|c|c|c|c|c|}
\hline \multirow{2}{*}{$\begin{array}{l}\text { Gelir } \\
\text { (TL) }\end{array}$} & \multirow{2}{*}{$\dot{\Xi}$} & \multirow{2}{*}{ Yaş } & \multicolumn{2}{|c|}{ Evet } & \multicolumn{2}{|c|}{ Hayır } \\
\hline & & & $\mathrm{N}$ & $\%$ & $\mathrm{~N}$ & $\%$ \\
\hline \multirow{4}{*}{$\begin{array}{c}500 \\
\text { den az }\end{array}$} & \multirow{2}{*}{$\mathrm{K}$} & $25-35$ & 3 & 100,0 & 0 & 0,0 \\
\hline & & $35-45$ & 3 & 60,0 & 2 & 40,0 \\
\hline & \multirow{2}{*}{ E } & $25-35$ & 5 & 100,0 & 0 & 0,0 \\
\hline & & $35-45$ & 3 & 100,0 & 0 & 0,0 \\
\hline \multirow{4}{*}{$\begin{array}{l}500- \\
1000\end{array}$} & \multirow{2}{*}{$\mathrm{K}$} & $25-35$ & 3 & 100,0 & 0 & 0,0 \\
\hline & & $35-45$ & 3 & 42,9 & 4 & 57,1 \\
\hline & \multirow{2}{*}{ E } & $25-35$ & 11 & 100,0 & 0 & 0,0 \\
\hline & & $35-45$ & 7 & 100,0 & 0 & 0,0 \\
\hline \multirow{4}{*}{$\begin{array}{l}1000- \\
3000\end{array}$} & \multirow{2}{*}{ K } & $25-35$ & 24 & 80,0 & 6 & 20,0 \\
\hline & & $35-45$ & 12 & 66,7 & 6 & 33,3 \\
\hline & \multirow{2}{*}{ E } & $25-35$ & 9 & 90,0 & 1 & 10,0 \\
\hline & & $35-45$ & 9 & 90,0 & 1 & 10,0 \\
\hline \multirow{4}{*}{$\begin{array}{c}3000- \\
5000\end{array}$} & \multirow{2}{*}{ K } & $25-35$ & 9 & 100,0 & 0 & 0,0 \\
\hline & & $35-45$ & 11 & 68,8 & 5 & 31,3 \\
\hline & \multirow{2}{*}{$\mathrm{E}$} & $25-35$ & 4 & 100,0 & 0 & 0,0 \\
\hline & & $35-45$ & 1 & 100,0 & 0 & 0,0 \\
\hline \multirow{4}{*}{$\begin{array}{l}5000 \\
\text { den } \\
\text { fazla }\end{array}$} & \multirow{2}{*}{ K } & $25-35$ & 0 & 0,0 & 0 & 0,0 \\
\hline & & $35-45$ & 4 & 80,0 & 1 & 20,0 \\
\hline & \multirow{2}{*}{$\mathrm{E}$} & $25-35$ & 0 & 0,0 & 0 & 0,0 \\
\hline & & $35-45$ & 3 & 100,0 & 0 & 0,0 \\
\hline
\end{tabular}

$\mathrm{X}^{2(1)}=10,939^{\mathrm{a}} ; \mathrm{p}<.05$

Sosyal sorumluluk projesi marka imajını etkiler mi? sorusuna verilen yanıtlara bakıldığında 25-35 yaş aralığında 39 kadın ve 29 erkek evet, 6 kadın ve 1 erkek hayır yanıtını vermiştir. 35-45 yaş aralığına bakıldığında ise kadınların 33'ü evet, 18'i hayır; erkeklerin ise 23'ü evet 1'i hayır yanıtını vermiştir. Ki-kare testi sonuçlarına bakıldığında p: ,001 çıkmıştır. Dolayısıyla sosyal sorumluluk projelerinin marka imajı üzerinde etkili olup olmadığına ilişkin kadın ve erkekler arasında anlamlı bir fark olduğu görülmektedir. 
Kadınlar erkeklere göre marka imajında sosyal sorumluluk projelerinin etkisinin daha çok olduğunu düşünmektedirler.

Tablo 6. Domestos'un Okullara Bağış Sosyal Sorumluluk Projesinden Haberiniz Var Mi? Sorusuna Verilen Yanitların Dağılımı

\begin{tabular}{|c|c|c|c|c|c|c|}
\hline \multirow{2}{*}{$\begin{array}{l}\text { Gelir } \\
\text { (TL) }\end{array}$} & \multirow{2}{*}{$\dot{\Xi}$} & \multirow{2}{*}{ Yaş } & \multicolumn{2}{|c|}{ Evet } & \multicolumn{2}{|c|}{ Hayır } \\
\hline & & & $\mathrm{N}$ & $\%$ & $\mathrm{~N}$ & $\%$ \\
\hline \multirow{4}{*}{$\begin{array}{c}500 ’ \\
\text { den az }\end{array}$} & \multirow{2}{*}{$\mathrm{K}$} & $25-35$ & 3 & 100,0 & 0 & 0,0 \\
\hline & & $35-45$ & 4 & 80,0 & 1 & 20,0 \\
\hline & \multirow{2}{*}{ E } & $25-35$ & 4 & 80,0 & 1 & 20,0 \\
\hline & & $35-45$ & 1 & 33,3 & 2 & 66,7 \\
\hline \multirow{4}{*}{$\begin{array}{l}500- \\
1000\end{array}$} & \multirow{2}{*}{ K } & $25-35$ & 2 & 66,7 & 1 & 33,3 \\
\hline & & $35-45$ & 7 & 100,0 & 0 & 0,0 \\
\hline & \multirow{2}{*}{ E } & $25-35$ & 7 & 63,6 & 4 & 36,4 \\
\hline & & $35-45$ & 5 & 71,4 & 2 & 28,6 \\
\hline \multirow{4}{*}{$\begin{array}{l}1000- \\
3000\end{array}$} & \multirow{2}{*}{ K } & $25-35$ & 25 & 83,3 & 5 & 16,7 \\
\hline & & $35-45$ & 14 & 77,8 & 4 & 22,2 \\
\hline & \multirow{2}{*}{ E } & $25-35$ & 4 & 40,0 & 6 & 60,0 \\
\hline & & $35-45$ & 9 & 90,0 & 1 & 10,0 \\
\hline \multirow{4}{*}{$\begin{array}{c}3000- \\
5000\end{array}$} & \multirow{2}{*}{ K } & $25-35$ & 8 & 88,9 & 1 & 11,1 \\
\hline & & $35-45$ & 12 & 75,0 & 4 & 25,0 \\
\hline & \multirow{2}{*}{$\mathrm{E}$} & $25-35$ & 2 & 50,0 & 2 & 50,0 \\
\hline & & $35-45$ & 1 & 100,0 & 0 & 0,0 \\
\hline \multirow{4}{*}{$\begin{array}{l}5000 \\
\text { 'den } \\
\text { fazla }\end{array}$} & \multirow{2}{*}{$\mathrm{K}$} & $25-35$ & 0 & 0,0 & 0 & 0,0 \\
\hline & & $35-45$ & 5 & 100,0 & 0 & 0,0 \\
\hline & \multirow{2}{*}{$\mathrm{E}$} & $25-35$ & 0 & 0,0 & 0 & 0,0 \\
\hline & & $35-45$ & 0 & 0,0 & 3 & 100,0 \\
\hline
\end{tabular}

$\mathrm{X}^{2(1)}=9,184^{\mathrm{a}} ; \mathrm{p}<.05$

Katılımcıların Domestos'un okullara bağış sosyal sorumluluk kampanyasından haberdar olup olmadıklarına yönelik soruya verdikleri yanıtın dağılımına bakıldığında 25-35 yaş aralığında 38 kadının kampanyadan haberdar olduğu, 7 kadının ise olmadığı görülmektedir. 25-35 yaş aralığındaki erkeklerden ise 17'si kampanyadan haberdarken 13'ü değildir. 35-45 yaş aralığında 42 kadın ve 16 erkek kampanyadan haberdar olduğunu belirtirken, 9 kadın ve 8 erkek haberdar olmadığını belirtmiştir. Dolayısıyla toplamda 80 kadın ve 33 erkek kampanyadan haberdarken, 16 kadın ve 21 erkek kampanyadan haberdar değildir. Ki-kare testi sonuçları da göstermiştir ki kadın ve erkekler arasında kampanyadan haberdar olma açısından anlamlı bir fark vardır (p: ,002). Bu, sonucu kadınların erkeklere göre markanın sosyal sorumluluk kampanyasına daha ilgili oldukları yönünde yorumlamak mümkündür.

\subsection{Domestos'un Okullara Bağıș Kampanyası Projesini Ölçmeye Yönelik İfadeler}

$\mathrm{Bu}$ bölümde 5'li Likert ölçeği ile hazırlanan ve Domestos'un sosyal sorumluluk kapsaminda değerlendirilen kampanyasına yönelik ifadelere verilen yanıtların analizlerine yer verilmiştir. Katılımcıların gelir düzeyleri rakamlarla kodlanmıştır. Buna göre; 1:500'den az, 2: 500-1000, 3: 1000-3000, 4: 3000-5000, ve 5: 5000 'den fazla geliri ifade etmektedir. Anketi cevaplayanların maddelere katılım düzeylerinde 1: Kesinlikle katılıyorum, 2: Katılıyorum, 3: Kararsızım, 4: Katılmıyorum, 5: Kesinlikle katılmıyorum ifadelerini temsil etmektedir.
Tablo 7. "Sosyal Sorumluluk Projeleri Ürün Tercihlerimde Önemlidir" Cümlesine Katılımcıların Verdiği Yanıtlar

\begin{tabular}{|c|c|c|c|c|c|c|c|c|c|}
\hline \multirow{3}{*}{$\begin{array}{c} \\
\text { G. } \\
\text { (TL) }\end{array}$} & & \multicolumn{4}{|c|}{ Kadın } & \multicolumn{4}{|c|}{ Erkek } \\
\hline & & \multicolumn{2}{|c|}{$25-35$} & \multicolumn{2}{|c|}{$35-45$} & \multicolumn{2}{|c|}{$25-35$} & \multicolumn{2}{|c|}{$35-45$} \\
\hline & & $\mathrm{N}$ & $\%$ & $\mathrm{~N}$ & $\%$ & $\bar{N}$ & $\%$ & $\mathrm{~N}$ & $\%$ \\
\hline \multirow{5}{*}{1} & 1 & 0 & 0,0 & 1 & 20,0 & 1 & 20,0 & 0 & 0,0 \\
\hline & 2 & 2 & 66,7 & 3 & 60,0 & & 20,0 & 2 & 66,7 \\
\hline & 3 & 1 & 33,3 & 1 & 20,0 & 2 & 40,0 & 1 & 33,3 \\
\hline & 4 & 4 & 0,0 & 0 & 0,0 & 1 & 20,0 & 0 & 0,0 \\
\hline & 5 & 0 & 0,0 & 0 & 0,0 & 1 & 0,0 & 0 & 0,0 \\
\hline \multirow{5}{*}{2} & 1 & 1 & 33,3 & 3 & 42,9 & 5 & 45,5 & 3 & 42,9 \\
\hline & 2 & 0 & 0,0 & 3 & 42,9 & 3 & 27,3 & 1 & 14,3 \\
\hline & 3 & 1 & 33,3 & 0 & 0,0 & 2 & 18,2 & 1 & 14,3 \\
\hline & 4 & 1 & 33,3 & 1 & 14,3 & 0 & 0,0 & 1 & 14,3 \\
\hline & 5 & 0 & 0,0 & 0 & 0,0 & 1 & 9,1 & 1 & 14,3 \\
\hline \multirow{5}{*}{3} & 1 & 6 & 20,0 & 2 & 11,1 & 1 & 10,0 & 3 & 30,0 \\
\hline & 2 & 15 & 50,0 & 10 & 55,6 & 5 & 50,0 & 3 & 30,0 \\
\hline & 3 & 7 & 23,3 & 5 & 27,8 & 2 & 20,0 & 2 & 20,0 \\
\hline & 4 & 2 & 6,7 & 1 & 5,6 & 2 & 20,0 & 0 & 0,0 \\
\hline & 5 & 0 & 0,0 & 0 & 0,0 & 0 & 0,0 & 2 & 20,0 \\
\hline \multirow{5}{*}{4} & 1 & 1 & 11,1 & 3 & 18,8 & 1 & 25,0 & 0 & 0,0 \\
\hline & 2 & 4 & 44,4 & 10 & 62,5 & 3 & 75,0 & 0 & 0,0 \\
\hline & 3 & 2 & 22,2 & 3 & 18,8 & 0 & 0,0 & 1 & 100 \\
\hline & 4 & 1 & 11,1 & 0 & 0,0 & 0 & 0,0 & 0 & 0,0 \\
\hline & 5 & 1 & 11,1 & 0 & 0,0 & 0 & 0,0 & 0 & 0,0 \\
\hline \multirow{5}{*}{5} & 1 & 0 & 0,0 & 2 & 40,0 & 0 & 0,0 & 0 & 0,0 \\
\hline & 2 & 0 & 0,0 & 2 & 40 & 0 & 0,0 & 1 & 33,3 \\
\hline & 3 & 0 & 0,0 & 0 & 0,0 & 0 & 0,0 & 0 & 0,0 \\
\hline & 4 & 0 & 0,0 & 0 & 0,0 & 0 & 0,0 & 0 & 0,0 \\
\hline & 5 & 0 & 0,0 & 0 & 0,0 & 0 & 0,0 & 0 & 0,0 \\
\hline
\end{tabular}

$\mathrm{X}^{2(4)=} 10,021^{\mathrm{a}} ; \mathrm{p}<.05$

Domestos'un okullara bağış kampanyası projesini ölçmeye yönelik ifadelerden ilki olan "sosyal sorumluluk projeleri ürün tercihlerimde önemlidir" cümlesine katılımcılardan 25-35 yaş aralığında olan toplam $8(17,8 \%)$ kadın kesinlikle katıliyorum, 21 (46,7\%) kadın katıliyorum, 11 (24,4\%) kadın kararsızım, 4 (8,9\%) kadın katılmıyorum, 1 (2,2\%) kadın ise kesinlikle katılmıyorum yanıtını vermiştir. 35-45 yaş aralığındaki kadınların ise 11 'i $(21,6 \%)$ kesinlikle katıliyorum, 28'i (54,9\%) katıliyorum, 9'u (17,6\%) kararsızım, 3'ü (5,9\%) katılmıyorum yanıtını vermiştir. 2535 yaş aralığındaki erkeklerin ise 8'i $(21,7 \%)$ kesinlikle katıliyorum, 12'si (40,0\%) katiliyorum, 6's1 (20,0\%) kararsızım, 3'ü (10,0\%) katılmıyorum, 1'i (3,3\%) de kesinlikle katılmıyorum yanıtını vermiştir. 35-45 yaş aralığındaki erkek katılımcılardan 6's1 (25,0\%) kesinlikle katıliyorum, 7'si (29,2\%) katıliyorum, 5'i (20,8\%) kararsızım, 1'i (4,2\%) katılmıyorum, 5'i (20,8\%) kesinlikle katılmıyorum yanıtını vermiştir. Gelir ve yaş dağılımı değişkenleri de dikkate alınarak yapılan ki-kare testi sonuçlarında p: ,040 çıkmıştır. Dolayısıyla kadın ve erkek katılımcılar arasında "sosyal sorumluluk projesi ürün tercihlerinde önemlidir" cümlesine verdikleri yanıtlarda anlamlı bir fark vardır. Kadınların marka tercihinde markanın yürüttüğü sosyal sorumluluk projelerinin etkili olduğunu söylemek mümkündür. 
Tablo 8. "Bir Ürünü Satın Alırken Sosyal Sorumluluk Projesi Yapıp Yapmadığına Dikkat Ederim" Cümlesine Katılımcıların Verdiği Yanitlar

\begin{tabular}{|c|c|c|c|c|c|c|c|c|c|}
\hline \multirow{3}{*}{$\begin{array}{c} \\
\text { G. } \\
\text { (TL) }\end{array}$} & & \multicolumn{4}{|c|}{ Kadın } & \multicolumn{4}{|c|}{ Erkek } \\
\hline & & \multicolumn{2}{|c|}{$25-35$} & \multicolumn{2}{|c|}{$35-45$} & \multicolumn{2}{|c|}{$25-35$} & \multicolumn{2}{|c|}{$35-45$} \\
\hline & & $\mathrm{N}$ & $\%$ & $\mathrm{~N}$ & $\%$ & $\mathrm{~N}$ & $\%$ & $\mathrm{~N}$ & $\%$ \\
\hline \multirow{5}{*}{1} & 1 & 0 & 0,0 & 0 & 0,0 & $\Omega$ & 0,0 & 2 & 66,7 \\
\hline & 2 & 2 & 66,7 & 1 & 20,0 & 2 & 40,0 & 0 & 0,0 \\
\hline & 3 & 1 & 33,3 & 2 & 40,0 & 2 & 40,0 & 1 & 33,3 \\
\hline & 4 & 0 & 0,0 & 1 & 20,0 & 0 & 0,0 & 0 & 0,0 \\
\hline & 5 & 0 & 0,0 & 1 & 20,0 & 1 & 20,0 & 0 & 0,0 \\
\hline \multirow{5}{*}{2} & 1 & 0 & 0,0 & 0 & 0,0 & 2 & 18,2 & 0 & 0,0 \\
\hline & 2 & 1 & 33,3 & 3 & 42,9 & 3 & 27,3 & 2 & 28,6 \\
\hline & 3 & 0 & 30,0 & 3 & 42,9 & 2 & 18,2 & 1 & 14,3 \\
\hline & 4 & 2 & 66,7 & 0 & 0,0 & 2 & 18,2 & 4 & 57,1 \\
\hline & 5 & 0 & 0,0 & 1 & 14,3 & 2 & 18,2 & 0 & 0,0 \\
\hline \multirow{5}{*}{3} & 1 & 3 & 10,0 & 2 & 11,1 & 0 & 0,0 & 1 & 10,0 \\
\hline & 2 & 16 & 53,3 & 4 & 22,2 & 4 & 40,0 & 1 & 10,0 \\
\hline & 3 & 7 & 23,3 & 7 & 38,9 & 4 & 40,0 & 4 & 40,0 \\
\hline & 4 & 4 & 13,3 & 3 & 16,7 & 1 & 10,0 & 3 & 30,0 \\
\hline & 5 & 0 & 0,0 & 2 & 11,1 & 1 & 10,0 & 1 & 10,0 \\
\hline \multirow{5}{*}{4} & 1 & 2 & 22,2 & 1 & 6,3 & 0 & 0,0 & 0 & 0,0 \\
\hline & 2 & 1 & 11,1 & 7 & 43,8 & 1 & 25,0 & 0 & 0,0 \\
\hline & 3 & 4 & 44,4 & 3 & 18,8 & 0 & 0,0 & 0 & 0,0 \\
\hline & 4 & 1 & 11,1 & 3 & 18,8 & 2 & 50,0 & 1 & 100 \\
\hline & 5 & 1 & 11,1 & 2 & 12,5 & 1 & 25,0 & 0 & 0,0 \\
\hline \multirow{5}{*}{5} & 1 & 0 & 0,0 & 0 & 0,0 & 0 & 0,0 & 2 & 66,7 \\
\hline & 2 & 0 & 0,0 & 2 & 40,0 & 0 & 0,0 & 1 & 33,3 \\
\hline & 3 & 0 & 0,0 & 3 & 60,0 & 0 & 0,0 & 0 & 0,0 \\
\hline & 4 & 0 & 0,0 & 0 & 0,0 & 0 & 0,0 & 0 & 0,0 \\
\hline & 5 & 0 & 0,0 & 0 & 0,0 & 0 & 0,0 & 0 & 0,0 \\
\hline
\end{tabular}

$\mathrm{X}^{2(4)=} 5,004^{\mathrm{a}} ; \mathrm{p}<.05$

Katılımcıların "bir ürünü satın alırken sosyal sorumluluk projesi yapıp yapmadığına dikkat ederim” cümlesine katılım oranlarına bakıldı̆̆ında 25-35 yaș aralı̆̆ındaki kadınların 5'i (11,1\%) kesinlikle katılıyorum, 20'si (44,4\%) katıliyorum, 12'si (26,7\%) kararsızım, 7'si (15,6\%) katılmiyorum, 1'i (2,2\%) ise kesinlikle katılmiyorum; erkeklerin 2'si (6,7\%) kesinlikle katılıyorum, 10'u (33,3\%) katılıyorum, 8'i (26,7\%) kararsızım, 5'i (16,7\%) katılmıyorum, 5'i (16,7\%) ise kesinlikle katılmıyorum yanıtını vermiştir. 35-45 yaş aralığındaki kadınların 3'ü (20,8\%) kesinlikle katılıyorum, 17'si (33,3\%) katılıyorum, 18'i (35,3\%) kararsızım, 7'si (13,7\%) katılmiyorum, 6's1 $(11,8 \%)$ kesinlikle katılmıyorum; erkeklerin 5'i $(20,8)$ kesinlikle katıliyorum, 4'ü (16,7\%) katılmıyorum, 6's1 (25,0\%) kararsızım, 8'i (33,3\%) katılmıyorum, 1'i (4,2\%) de kesinlikle katılmıyorum yanıtını vermiştir. Ki-kare testi sonuçları değerlendirildiğinde ise kadınlarla erkekler arasında ürün tercihlerinde markanın sosyal sorumluluk projesi yapıp yapmadığına dikkat etme açısından anlamlı bir fark bulunmaktadır (p: ,287). Kadınlar ürün satın alırken markanın sosyal sorumluluk projesi yapıp yapmadığına erkeklere göre daha çok dikkat etmektedirler.
Tablo 9. "Sosyal Sorumluluk Projeleri Markayı Olumlu Yönde Etkiler" Cümlesine Katılımcıların Verdiği Yanıtlar

\begin{tabular}{|c|c|c|c|c|c|c|c|c|c|}
\hline \multirow{3}{*}{$\begin{array}{c} \\
\text { G. } \\
\text { (TL) }\end{array}$} & & \multicolumn{4}{|c|}{ Kadın } & \multicolumn{4}{|c|}{ Erkek } \\
\hline & & \multicolumn{2}{|c|}{$25-35$} & \multicolumn{2}{|c|}{$35-45$} & \multicolumn{2}{|c|}{$25-35$} & \multicolumn{2}{|c|}{$35-45$} \\
\hline & & $\mathrm{N}$ & $\%$ & $\mathrm{~N}$ & $\%$ & $\mathrm{~N}$ & $\%$ & $\mathrm{~N}$ & $\%$ \\
\hline \multirow{5}{*}{1} & 1 & 0 & 0,0 & 1 & 20,0 & 1 & 20,0 & 2 & 66,7 \\
\hline & 2 & 2 & 66,7 & 3 & 60,0 & $J$ & 60,0 & 0 & 0,0 \\
\hline & 3 & 0 & 0,0 & 1 & 20,0 & 1 & 20,0 & 1 & 33,3 \\
\hline & 4 & 1 & 33,3 & 0 & 0,0 & 0 & 0,0 & 0 & 0,0 \\
\hline & 5 & 0 & 0,0 & 0 & 0,0 & 0 & 0,0 & 0 & 0,0 \\
\hline \multirow{5}{*}{2} & & 1 & 33,3 & 3 & 42,9 & 6 & 54,3 & 3 & 42,9 \\
\hline & 2 & 1 & 33,3 & 4 & 57,1 & 3 & 27,3 & 3 & 42,9 \\
\hline & 3 & 4 & 0,0 & 0 & 0,0 & 2 & 18,2 & 0 & 0,0 \\
\hline & 4 & 1 & 33,3 & 0 & 0,0 & 0 & 0,0 & 1 & 14,3 \\
\hline & 5 & 0 & 0,0 & 0 & 0,0 & 0 & 0,0 & 0 & 0,0 \\
\hline \multirow{5}{*}{3} & 1 & 19 & 63,3 & 2 & 11,1 & 1 & 10,0 & 3 & 30,0 \\
\hline & 2 & 6 & 20,0 & 10 & 55,6 & 5 & 50,0 & 7 & 70,0 \\
\hline & 3 & 0 & 0,0 & 3 & 33,3 & 4 & 40,0 & 0 & 0,0 \\
\hline & 4 & 2 & 6,7 & 0 & 0,0 & 0 & 0,0 & 0 & 0,0 \\
\hline & 5 & 0 & 0,0 & 0 & 0,0 & 0 & 0,0 & 0 & 0,0 \\
\hline \multirow{5}{*}{4} & 1 & 3 & 33,3 & 5 & 31,3 & 2 & 50,0 & 0 & 0,0 \\
\hline & 2 & 5 & 55,6 & 8 & 50,0 & 2 & 50,0 & 0 & 0,0 \\
\hline & 3 & 0 & 0,0 & 1 & 6,3 & 0 & 0,0 & 1 & 100 \\
\hline & 4 & 0 & 0,0 & 0 & 0,0 & 0 & 0,0 & 0 & 0,0 \\
\hline & 5 & 1 & 11,1 & 2 & 12,5 & 0 & 0,0 & 0 & 0,0 \\
\hline \multirow{5}{*}{5} & 1 & 0 & 0,0 & 3 & 60,0 & 0 & 0,0 & 1 & 33,3 \\
\hline & 2 & 0 & 0,0 & 2 & 40,0 & 0 & 0,0 & 2 & 66,7 \\
\hline & 3 & 0 & 0,0 & 0 & 0,0 & 0 & 0,0 & 0 & 0,0 \\
\hline & 4 & 0 & 0,0 & 0 & 0,0 & 0 & 0,0 & 0 & 0,0 \\
\hline & 5 & 0 & 0,0 & 0 & 0,0 & 0 & 0,0 & 0 & 0,0 \\
\hline
\end{tabular}

$\mathrm{X}^{2(4)}=6,254^{\mathrm{a}} ; \mathrm{p}<.05$

Katılımciların "sosyal sorumluluk projeleri markayı olumlu yönde etkiler" cümlesine katılım durumlarına bakıldığında 25-35 yaş aralığındaki kadınların 23'ü $(51,1 \%)$ kesinlikle katıliyorum, 14'ü (31,1\%) kat1liyorum, 4'ü (8,9\%) katılmıyorum, 4'ü $(8,9 \%)$ kesinlikle katılmıyorum yanıtını verirken aynı yaş grubundaki erkeklerin 10'u (33,3\%) kesinlikle katılıyorum, 13'ü (43,3\%) katılıyorum, 7'si $(23,3 \%)$ kararsızım yanıtını vermiştir. Kadınlarda kararsızım, erkeklerde ise katılmıyorum ve kesinlikle katılmıyorum yanıtlarını veren katılıme bulunmamaktadır. 35-45 yaş aralığındaki kadınların 14'ü (15,65\%) kesinlikle katıliyorum, 37'si (52,9\%) kat1liyorum, 8'i (15,7\%) kararsızım, 2'si (3,9\%) kesinlikle katılmıyorum yanıtını verirken, katılmıyorum yanıtını veren olmamıştır. 35-45 yaş aralığındaki erkeklerin 9'u (37,5\%) kesinlikle katılıyorum, 12'si (50,0\%) katıliyorum, 2'si (8,3\%) kararsızım, 1'i $(4,2 \%)$ katılmıyorum yanıtını verirken kesinlikle katılmıyorum yanıtını veren erkek katılımcı olmamıştır. Katılımcıların verdikleri yanıtlar değerlendirildiğinde kadınlar ve erkekler arasında sosyal sorumluluk projeleri markayı olumlu yönde etkiler cümlesine katılım açısından anlamlı bir fark olduğu görülmektedir (p: ,181). Kadınlar, erkeklere göre sosyal sorumluluk projelerinin marka imajını olumlu yönde etkilediğini daha çok düşünmektedirler. 
Tablo 10. "Ürün Tercih Ederken Sosyal Sorumluluk Projelerini Göz Önünde Bulundurmam" Cümlesine Katılımcıların Verdiğ Yanitlar

\begin{tabular}{|c|c|c|c|c|c|c|c|c|c|}
\hline \multirow{3}{*}{$\begin{array}{c} \\
\text { G. } \\
\text { (TL) }\end{array}$} & & \multicolumn{4}{|c|}{ Kadın } & \multicolumn{4}{|c|}{ Erkek } \\
\hline & & \multicolumn{2}{|c|}{$25-35$} & \multicolumn{2}{|c|}{$35-45$} & \multicolumn{2}{|c|}{$25-35$} & \multicolumn{2}{|c|}{$35-45$} \\
\hline & & $\mathrm{N}$ & $\%$ & $\mathrm{~N}$ & $\%$ & $\bar{N}$ & $\%$ & $\mathrm{~N}$ & $\%$ \\
\hline \multirow{5}{*}{1} & 1 & 1 & 33,3 & 0 & 0,0 & 1 & 20,0 & 1 & 33,3 \\
\hline & 2 & 0 & 0,0 & 2 & 40,0 & & 20,0 & 0 & 0,0 \\
\hline & 3 & 2 & 66,7 & 1 & 20,0 & 1 & 20,0 & 0 & 0,0 \\
\hline & 4 & 0 & 0,0 & 1 & 20,0 & 1 & 20,0 & 1 & 33,3 \\
\hline & 5 & 0 & 0,0 & 1 & 20,0 & 1 & 20,0 & 1 & 33,3 \\
\hline \multirow{5}{*}{2} & 1 & 0 & 0,0 & 0 & 0,0 & 0 & 0,0 & 1 & 14,3 \\
\hline & 2 & 1 & 33,3 & 1 & 14,3 & 2 & 18,2 & 2 & 28,6 \\
\hline & 3 & 1 & 33,3 & 3 & 42,9 & 2 & 18,2 & 0 & 0,0 \\
\hline & 4 & 1 & 33,3 & 3 & 42,9 & 5 & 45,5 & 1 & 14,3 \\
\hline & 5 & 0 & 0,0 & 0 & 0,0 & 2 & 18,2 & 3 & 42,9 \\
\hline \multirow{5}{*}{3} & 1 & 6 & 20,0 & 1 & 5,6 & 0 & 0,0 & 0 & 0,0 \\
\hline & 2 & 9 & 30,0 & 5 & 27,8 & 4 & 40,0 & 2 & 20,0 \\
\hline & 3 & 5 & 16,7 & 7 & 38,9 & 0 & 0,0 & 0 & 0,0 \\
\hline & 4 & 10 & 33,3 & 4 & 22,2 & 5 & 50,0 & 2 & 20,0 \\
\hline & 5 & 0 & 0,0 & 1 & 5,6 & 1 & 10,0 & 6 & 60,0 \\
\hline \multirow{5}{*}{4} & 1 & 4 & 44,4 & 0 & 0,0 & 1 & 25,0 & 0 & 0,0 \\
\hline & 2 & 1 & 11,1 & 5 & 31,3 & 0 & 0,0 & 0 & 0,0 \\
\hline & 3 & 4 & 44,4 & 2 & 12,5 & 1 & 25,0 & 0 & 0,0 \\
\hline & 4 & 0 & 0,0 & 5 & 31,3 & 0 & 0,0 & 0 & 0,0 \\
\hline & 5 & 0 & 0,0 & 4 & 25,0 & 2 & 15,4 & 1 & 100 \\
\hline \multirow{5}{*}{5} & 1 & 0 & 0,0 & 0 & 0,0 & 0 & 0,0 & 0 & 0,0 \\
\hline & 2 & 0 & 0,0 & 1 & 20,0 & 0 & 0,0 & 3 & 100 \\
\hline & 3 & 0 & 0,0 & 3 & 60,0 & 0 & 0,0 & 0 & 0,0 \\
\hline & 4 & 0 & 0,0 & 1 & 20,0 & 0 & 0,0 & 0 & 0,0 \\
\hline & 5 & 0 & 0,0 & 0 & 0,0 & 0 & 0,0 & 0 & 0,0 \\
\hline
\end{tabular}

$\mathrm{X}^{2(4)=22,899^{\mathrm{a}} ; \mathrm{p}<.05}$

Katılımcıların "ürün tercih ederken sosyal sorumluluk projelerini göz önünde bulundurmam” cümlesine verdikleri yanıtların dağılımına bakıldığında 25-35 yaş aralığındaki kadınların 11'i (24,4\%) kesinlikle katılıyorum, 11 'i (24,4\%) katıliyorum, 12'si (26,7\%) kararsızım, 11'i (24,4) katılmıyorum yanıtını vermiştir. Kesinlikle katılmıyorum cevabını veren ise olmamıștır. Aynı yaş aralığındaki erkeklerin 2'si (6,7\%) kesinlikle katılıyorum, 7'si (23,3\%) katılıyorum, 4'ü (13,3\%) kararsızım, 11'i (36,7\%) katılmıyorum, 6's1 $(20,0 \%)$ da kesinlikle katılmıyorum yanıtını vermiştir. 35-45 yaş aralığındaki kadınların 1'i (2,0\%) kesinlikle katılıyorum, 14'ü (27,5\%) katılıyorum, 16'sı (31,4\%) kararsızım, 14'ü (27,5\%) katılmıyorum, 6's1 $(11,8 \%)$ kesinlikle katılmıyorum yanıtını vermiştir. Erkeklerin ise 2'si $(66,7 \%)$ kesinlikle kat1lyyorum, 7'si (29,2\%) katıliyorum, 4'ü (16,7\%) katılmiyorum, 11'i $(45,8 \%)$ kesinlikle katılmıyorum yanıtını verirken kararsızım yanıtını veren katılımcı olmamıștır. Ki Kare testi sonucunda p: ,000 çıkmıştır. Dolayısıyla ürün tercih ederken sosyal sorumluluk projelerini göz önünde bulundurma açısından kadın ve erkek katılımcılar arasında anlamlı bir fark vardır. Kadınlar ürün tercihlerinde sosyal sorumluluk projelerini erkeklere göre daha çok göz önünde bulundurmaktadırlar.
Tablo 11. "Sosyal Sorumluluk Projeleri Markanın Ürün Satışını Etkilemez" Cümlesine Katılımcıların Verdiği Yanıtlar

\begin{tabular}{|c|c|c|c|c|c|c|c|c|c|}
\hline \multirow{3}{*}{$\begin{array}{c} \\
\text { G. } \\
\text { (TL) }\end{array}$} & & \multicolumn{4}{|c|}{ Kadın } & \multicolumn{4}{|c|}{ Erkek } \\
\hline & & \multicolumn{2}{|c|}{$25-35$} & \multicolumn{2}{|c|}{$35-45$} & \multicolumn{2}{|c|}{$25-35$} & \multicolumn{2}{|c|}{$35-45$} \\
\hline & & $\mathrm{N}$ & $\%$ & $\mathrm{~N}$ & $\%$ & $\mathrm{~N}$ & $\%$ & $\mathrm{~N}$ & $\%$ \\
\hline \multirow{5}{*}{1} & 1 & 0 & 0,0 & 0 & 0,0 & 1 & 20,0 & 0 & 0,0 \\
\hline & 2 & 0 & 0,0 & 1 & 20,0 & & 0,0 & 0 & 0,0 \\
\hline & 3 & 1 & 33,3 & 0 & 0,0 & 2 & 40,0 & 1 & 33,3 \\
\hline & 4 & 2 & 66,7 & 2 & 40,0 & 1 & 20,0 & 2 & 66,7 \\
\hline & 5 & 0 & 0,0 & 2 & 40,0 & 1 & 20,0 & 0 & 0,0 \\
\hline \multirow{5}{*}{2} & & 0 & 0,0 & 0 & 0,0 & 0 & 0,0 & 1 & 14,3 \\
\hline & 2 & 0 & 0,0 & 3 & 42,9 & 3 & 27,3 & 0 & 0,0 \\
\hline & 3 & 0 & 0,0 & 1 & 14,3 & 1 & 9,1 & 1 & 14,3 \\
\hline & 4 & 2 & 66,7 & 1 & 14,3 & 5 & 45,5 & 3 & 42,9 \\
\hline & 5 & 1 & 33,3 & 2 & 28,6 & 2 & 18,2 & 2 & 28,6 \\
\hline \multirow{5}{*}{3} & 1 & 3 & 10,0 & 2 & 11,1 & 1 & 10,0 & 3 & 30,0 \\
\hline & 2 & 3 & 10,0 & 3 & 16,7 & 1 & 10,0 & 3 & 30,0 \\
\hline & 3 & 5 & 16,7 & 1 & 5,6 & 1 & 10,0 & 1 & 10,0 \\
\hline & 4 & 17 & 56,7 & 8 & 44,4 & 3 & 30,0 & 2 & 20,0 \\
\hline & 5 & 2 & 6,7 & 4 & 22,2 & 4 & 40,0 & 1 & 10,0 \\
\hline \multirow{5}{*}{4} & 1 & 1 & 11,1 & 1 & 0,0 & 1 & 25,0 & 0 & 0,0 \\
\hline & 2 & 1 & 11,1 & 1 & 0,0 & 1 & 25,0 & 0 & 0,0 \\
\hline & 3 & 2 & 22,2 & 2 & 12,5 & 1 & 25,0 & 0 & 0,0 \\
\hline & 4 & 4 & 44,4 & 6 & 37,5 & 1 & 25,0 & 0 & 0,0 \\
\hline & 5 & 1 & 11,1 & 6 & 37,5 & 0 & 0,0 & 1 & 100 \\
\hline \multirow{5}{*}{5} & 1 & 0 & 0,0 & 0 & 0,0 & 0 & 0,0 & 0 & 0,0 \\
\hline & 2 & 0 & 0,0 & 2 & 40,0 & 0 & 0,0 & 0 & 0,0 \\
\hline & 3 & 0 & 0,0 & 1 & 20,0 & 0 & 0,0 & 0 & 0,0 \\
\hline & 4 & 0 & 0,0 & 0 & 0,0 & 0 & 0,0 & 2 & 66,7 \\
\hline & 5 & 0 & 0,0 & 2 & 40,0 & 0 & 0,0 & 1 & 33,3 \\
\hline
\end{tabular}

$\mathrm{X}^{2(4)=} 1,887^{\mathrm{a}} ; \mathrm{p}>.05$

Katılımcıların "sosyal sorumluluk projeleri markanın ürün satışını etkilemez" cümlesine verdikleri yanıtların dağılımına bakıldığında $25-35$ yaş aralığındaki kadınların 4'ünün $(8,9 \%)$ kesinlikle katılıyorum, 4'ünün $(8,9 \%)$ katıliyorum, 8'inin (17,8\%) kararsızım, 25'inin $(55,6 \%)$ katılmıyorum, 4'ünün (8,9\%) de kesinlikle katılmıyorum; erkeklerin 3'ünün $(10,0 \%)$ kesinlikle katılıyorum, 5'inin $(16,7 \%)$ katıliyorum, 5'inin (16,7\%) kararsızım, 10'unun $(33,3 \%)$ kesinlikle katılmıyorum, 7'sinin (23,3\%) de kesinlikle katılmıyorum yanıtını verdiğin görülmektedir. 35-45 yaş aralığındaki kadınların ise 3'ü (5,9\%) kesinlikle katıliyorum, 10'u (19,6\%) kat1liyorum, 5'i (9,8\%) kararsızım, 17'si (33,3\%) katılmıyorum, 16's1 (31,4\%) kesinlikle katılmiyorum; erkeklerin 4'ü (16,7\%) kesinlikle katıliyorum, 3'ü (12,5\%) kat1liyorum, 3'ü (12,5\%) kararsızım, 9'u (37,5\%) katılmıyorum, 5'i (20,8\%) kesinlikle katılmıyorum yanıtını vermiştir. Ki kare testi sonucunda p: ,757 çıkmıştır. Dolayısıyla kadınlarla erkekler arasında sosyal sorumluluk projeleri markanın ürün satışını etkilemez cümlesine verilen yanıtlar açısından anlamlı bir fark yoktur. 
Tablo 12. "Domestos Markas1 Sosyal Sorumluluk Projelerine Önem Vermektedir" Cümlesine Katılımcıların Verdiği Yanıtlar

\begin{tabular}{|c|c|c|c|c|c|c|c|c|c|}
\hline \multirow{3}{*}{$\begin{array}{c} \\
\text { G. } \\
\text { (TL) }\end{array}$} & & \multicolumn{4}{|c|}{ Kadın } & \multicolumn{4}{|c|}{ Erkek } \\
\hline & & \multicolumn{2}{|c|}{$25-35$} & \multicolumn{2}{|c|}{$35-45$} & \multicolumn{2}{|c|}{$25-35$} & \multicolumn{2}{|c|}{$35-45$} \\
\hline & & $\mathrm{N}$ & $\%$ & $\mathrm{~N}$ & $\%$ & $\bar{N}$ & $\%$ & $\mathrm{~N}$ & $\%$ \\
\hline \multirow{5}{*}{1} & 1 & 1 & 33,3 & 1 & 20,0 & 2 & 40,0 & 1 & 33,3 \\
\hline & 2 & 1 & 33,3 & 3 & 60,0 & & 20,0 & 0 & 0,0 \\
\hline & 3 & 1 & 33,3 & 1 & 20,0 & 1 & 20,0 & 2 & 66,7 \\
\hline & 4 & 0 & 0,0 & 0 & 0,0 & 1 & 20,0 & 0 & 0,0 \\
\hline & 5 & 0 & 0,0 & 0 & 0,0 & 0 & 0,0 & 0 & 0,0 \\
\hline \multirow{5}{*}{2} & & 1 & 33,3 & 0 & 0,0 & 1 & 9,1 & 2 & 28,6 \\
\hline & 2 & 1 & 33,3 & 4 & 57,1 & 6 & 54,5 & 2 & 28,6 \\
\hline & 3 & 1 & 33,3 & 3 & 42,9 & 4 & 36,4 & 3 & 42,9 \\
\hline & 4 & 0 & 0,0 & 0 & 0,0 & 0 & 0,0 & 0 & 0,0 \\
\hline & 5 & 0 & 0,0 & 0 & 0,0 & 0 & 0,0 & 0 & 0,0 \\
\hline \multirow{5}{*}{3} & 1 & 5 & 16,7 & 2 & 11,1 & 1 & 10,0 & 0 & 0,0 \\
\hline & 2 & 11 & 36,7 & 9 & 50,0 & 3 & 30,0 & 4 & 40,0 \\
\hline & 3 & 5 & 16,7 & 6 & 33,3 & 5 & 50,0 & 5 & 50,0 \\
\hline & 4 & 5 & 16,7 & 1 & 5,6 & 1 & 10,0 & 1 & 10,0 \\
\hline & 5 & 4 & 13,3 & 0 & 0,0 & 0 & 0,0 & 0 & 0,0 \\
\hline \multirow{5}{*}{4} & 1 & 1 & 11,1 & 2 & 12,5 & 0 & 0,0 & 0 & 0,0 \\
\hline & 2 & 4 & 44,4 & 6 & 37,5 & 1 & 25,0 & 0 & 0,0 \\
\hline & 3 & 2 & 22,2 & 6 & 37,5 & 3 & 75,0 & 1 & 100 \\
\hline & 4 & 1 & 11,1 & 2 & 12,5 & $\overline{0}$ & 0,0 & 0 & 0,0 \\
\hline & 5 & 1 & 11,1 & 0 & 0,0 & 0 & 0,0 & 0 & 0,0 \\
\hline \multirow{5}{*}{5} & 1 & 0 & 0,0 & 1 & 20,0 & 0 & 0,0 & 2 & 66,7 \\
\hline & 2 & 0 & 0,0 & 2 & 40,0 & 0 & 0,0 & 1 & 33,3 \\
\hline & 3 & 0 & 0,0 & 1 & 20,0 & 0 & 0,0 & 0 & 0,0 \\
\hline & 4 & 0 & 0.0 & 1 & 20,0 & 0 & 0.0 & 0 & 0.0 \\
\hline & 5 & 0 & 0,0 & 0 & 0,0 & 0 & 0,0 & 0 & 0,0 \\
\hline
\end{tabular}

$\mathrm{X}^{2(4)=} 7,750^{\mathrm{a}} ; \mathrm{p}<.05$

"Domestos markası sosyal sorumluluk projelerine önem vermektedir" cümlesine verilen yanıtların dağılımına bakıldığında 25-35 yaş aralığındaki kadınların 8'inin $(17,8 \%)$ kesinlikle katıliyorum, 17'sinin (37,8\%) katılıyorum, 9'unun (20,0\%) kararsızım, 6'sının (13,3\%) katılmıyorum, 5'inin (11,1\%) kesinlikle katılmıyorum yanıtını verdikleri görülmektedir. Aynı yaş aralığındaki erkeklerin 4'ü (13,3\%) kesinlikle kat1lyyorum, 11'i (36,7\%) katılıyorum, 13'ü (43,3\%) kararsızım, 2'si (6,7\%) katılmıyorum yanıtını verirken kesinlikle katılmıyorum yanıtını veren olmamıştır. 35-45 yaş aralığında ise kadınların 6'sı $(11,8 \%)$ kesinlikle katılıyorum, 24'ü (47,1\%) katılıyorum, 17'si (33,3\%) kararsızım, 4'ü $(7,85)$ katılmıyorum yanıtını verirken; 5 (20,8\%) erkek kesinlikle katıliyorum, 7 (29,2\%) erkek katıliyorum, $11(45,8 \%)$ erkek kararsızım, $1(4,2 \%)$ erkek ise katılmıyorum yanıtını vermiştir. Kesinlikle katılmıyorum yanıtını veren kadın ve erkek ise bulunmamaktadır. $\mathrm{Ki}$ kare testi sonuçları değerlendirildiğinde p: ,101 çıkmıştır. Dolayısıyla kadın ve erkeler arasında Domestos markası sosyal sorumluluk projesine önem vermektedir cümlesine katılım oranı açısından anlamlı bir fark vardır. Kadınlar erkeklere göre Domestos markasının sosyal sorumluluk projelerine daha çok önem verdiğini düşünmektedirler.
Tablo 13. "Dometos Yapmıș Olduğu Sosyal Sorumluluk Projesi ile Topluma Katkı Sağlıyor" Cümlesine Katılımcıların Verdiği Yanitlar

\begin{tabular}{|c|c|c|c|c|c|c|c|c|c|}
\hline \multirow{3}{*}{$\begin{array}{c} \\
\text { G. } \\
\text { (TL) }\end{array}$} & & \multicolumn{4}{|c|}{ Kadın } & \multicolumn{4}{|c|}{ Erkek } \\
\hline & & \multicolumn{2}{|c|}{$25-35$} & \multicolumn{2}{|c|}{$35-45$} & \multicolumn{2}{|c|}{$25-35$} & \multicolumn{2}{|c|}{$35-45$} \\
\hline & & $\mathrm{N}$ & $\%$ & $\mathrm{~N}$ & $\%$ & $\overline{\mathrm{N}}$ & $\%$ & $\mathrm{~N}$ & $\%$ \\
\hline \multirow{5}{*}{1} & 1 & 1 & 33,3 & 4 & 80,0 & 1 & 20,0 & 1 & 33,3 \\
\hline & 2 & 2 & 66,7 & 1 & 20,0 & 4 & 80,0 & 2 & 66,7 \\
\hline & 3 & 0 & 0,0 & 0 & 0,0 & 0 & 0,0 & 0 & 0,0 \\
\hline & 4 & 0 & 0,0 & 0 & 0,0 & 0 & 0,0 & 0 & 0,0 \\
\hline & 3 & 0 & 0,0 & 0 & 0,0 & 0 & 0,0 & 0 & 0,0 \\
\hline \multirow{5}{*}{2} & 1 & 0 & 0,0 & 1 & 14,3 & 2 & 18,2 & 1 & 14,3 \\
\hline & 2 & 1 & 33,3 & 3 & 42,9 & 7 & 63,6 & 3 & 42,9 \\
\hline & 3 & 2 & 66,7 & 2 & 28,6 & 2 & 18,2 & 2 & 28,6 \\
\hline & 4 & 0 & 0,0 & 1 & 14,3 & 0 & 0,0 & 0 & 0,0 \\
\hline & 5 & 0 & 0,0 & 0 & 0,0 & 0 & 0,0 & 1 & 14,3 \\
\hline \multirow{5}{*}{3} & 1 & 7 & 23,3 & 3 & 16,7 & 1 & 10,0 & 0 & 0,0 \\
\hline & 2 & 17 & 16,5 & 11 & 61,1 & 5 & 50,0 & 3 & 30,0 \\
\hline & 3 & 6 & 20,0 & 3 & 16,7 & 3 & 30,0 & 4 & 40,0 \\
\hline & 4 & 0 & 0,0 & 0 & 0,0 & 1 & 10,0 & 1 & 10,0 \\
\hline & 5 & 0 & 0,0 & 1 & 5,6 & 0 & 0,0 & 2 & 20,0 \\
\hline \multirow{5}{*}{4} & 1 & 2 & 22,2 & 1 & 6,3 & 0 & 0,0 & 0 & 0,0 \\
\hline & 2 & 4 & 44,4 & 9 & 56,3 & 2 & 50,0 & 1 & 100 \\
\hline & 3 & 4 & 33,3 & 4 & 25,0 & 2 & 50,0 & 0 & 0,0 \\
\hline & 4 & 0 & 0,0 & 1 & 6,3 & 0 & 0,0 & 0 & 0,0 \\
\hline & 5 & 0 & 0,0 & 1 & 6,3 & 0 & 0,0 & 0 & 0,0 \\
\hline \multirow{5}{*}{5} & 1 & 0 & 0,0 & 0 & 0,0 & 0 & 0,0 & 2 & 66,7 \\
\hline & 2 & 0 & 0,0 & 5 & 100 & 0 & 0,0 & 0 & 0,0 \\
\hline & 3 & 0 & 0,0 & 0 & 0,0 & 0 & 0,0 & 1 & 33,3 \\
\hline & 4 & 0 & 0,0 & 0 & 0,0 & 0 & 0,0 & 0 & 0,0 \\
\hline & 5 & 0 & 0,0 & 0 & 0,0 & 0 & 0,0 & $\overline{0}$ & 0,0 \\
\hline
\end{tabular}

$\mathrm{X}^{2(4)=} 2,637^{\mathrm{a}} ; \mathrm{p}>.05$

"Domestos yapmış olduğu sosyal sorumluluk projesi ile topluma katkı sağlıyor" cümlesine 25-35 yaş aralığındaki kadınların 10'u (22,2\%) kesinlikle katılıyorum, 24'ü $(53,3 \%)$ katıliyorum, 11 'i $(24,4 \%)$ kararsızım yanıtını vermiştir. Katılmıyorum ve kesinlikle katılmıyorum yanıtını veren olmamıștır. Aynı yaş aralığındaki erkeklerin 4'ü $(13,3 \%)$ kesinlikle katıliyorum, 18'i (60,0\%) katılıyorum, 7'si (23,3\%) kararsızım, 1'i ise katılmıyorum yanıtını vermiştir. Kesinlikle katılmıyorum yanıtını veren olmamıştır. 35-45 yaş aralığındaki kadınların 9'u (17,6\%) kesinlikle kat1liyorum, 29'u (56,9\%) kat1liyorum, 9'u (17,6\%) kararsızım, 2'si (3,9\%) katılmıyorum, 2'si (3,9\%) kesinlikle katılmıyorum; erkeklerin 4'ü (16,7\%) kesinlikle katıliyorum, 9'u (37,5\%) katıliyorum, 7'si (29,2\%) kararsızım, 1'i (4,2\%) katılmıyorum, 3'ü (12,5) ise kesinlikle katılmıyorum yanıtını vermiştir. Ki kare testi sonuçlarına bakıldığında da kadınlarla erkekler arasında Domestos yapmış olduğu sosyal sorumluluk projesi ile topluma katkı sağlıyor cümlesine katılım açısından anlamlı bir fark olmadığı görülmüştür (p: ,620). 
Tablo 14. "Domestos Okullara Hijyen Desteği Vererek Temizlik Bilincine Katkı Sağlıyor" Cümlesine Katılımcıların Verdiği Yanitlar

\begin{tabular}{|c|c|c|c|c|c|c|c|c|c|}
\hline \multirow{3}{*}{$\begin{array}{c} \\
\text { G. } \\
\text { (TL) }\end{array}$} & & \multicolumn{4}{|c|}{ Kadın } & \multicolumn{4}{|c|}{ Erkek } \\
\hline & & \multicolumn{2}{|c|}{$25-35$} & \multicolumn{2}{|c|}{$35-45$} & \multicolumn{2}{|c|}{$25-35$} & \multicolumn{2}{|c|}{$35-45$} \\
\hline & & $\mathrm{N}$ & $\%$ & $\mathrm{~N}$ & $\%$ & $\mathrm{~N}$ & $\%$ & $\mathrm{~N}$ & $\%$ \\
\hline \multirow{5}{*}{1} & 1 & 0 & 0,0 & 4 & 80,0 & 3 & 60,0 & 2 & 66,7 \\
\hline & 2 & 2 & 66,7 & 1 & 20,0 & 2 & 40,0 & 1 & 33,3 \\
\hline & 3 & 0 & 0,0 & 0 & 0,0 & 0 & 0,0 & 0 & 0,0 \\
\hline & 4 & 0 & 0,0 & 0 & 0,0 & 0 & 0,0 & 0 & 0,0 \\
\hline & 5 & 1 & 33,3 & 0 & 0,0 & 0 & 0,0 & 0 & 0,0 \\
\hline \multirow{5}{*}{2} & 1 & 0 & 0,0 & 3 & 42,9 & 2 & 18,2 & 2 & 28,6 \\
\hline & 2 & 3 & 100 & 2 & 28,6 & 7 & 63,6 & 3 & 42,9 \\
\hline & 3 & 0 & 0,0 & 2 & 28,6 & 1 & 9,1 & 1 & 14,3 \\
\hline & 4 & 0 & 0,0 & 0 & 0,0 & 0 & 0,0 & 0 & 0,0 \\
\hline & 5 & 0 & 0,0 & 0 & 0,0 & 1 & 9,1 & 1 & 14,3 \\
\hline \multirow{5}{*}{3} & 1 & 11 & 36,6 & 7 & 38,9 & 5 & 50,0 & 0 & 0,0 \\
\hline & 2 & 14 & 46,7 & 8 & 44,4 & 4 & 40,0 & 5 & 50,0 \\
\hline & 3 & 3 & 10,0 & 2 & 11,1 & 0 & 0,0 & 0 & 0,0 \\
\hline & 4 & 0 & 0,0 & 1 & 5,6 & 1 & 10,0 & 3 & 30,0 \\
\hline & 5 & 2 & 6,7 & 0 & 0,0 & 0 & 0,0 & 2 & 20,0 \\
\hline \multirow{5}{*}{4} & 1 & 2 & 22,2 & 4 & 25,0 & 0 & 0,0 & 0 & 0,0 \\
\hline & 2 & 4 & 44,4 & 10 & 62,5 & 3 & 75,5 & 1 & 100 \\
\hline & 3 & 2 & 22,2 & 2 & 12,5 & 1 & 25,0 & 0 & 0,0 \\
\hline & 4 & 1 & 11,1 & 0 & 0,0 & 0 & 0,0 & 0 & 0,0 \\
\hline & 5 & 0 & 0,0 & 0 & 0,0 & 0 & 0,0 & 0 & 0,0 \\
\hline \multirow{5}{*}{5} & 1 & 0 & 0,0 & 2 & 66,7 & 0 & 0,0 & 4 & 50,0 \\
\hline & 2 & 0 & 0,0 & 1 & 33,3 & 0 & 0,0 & 3 & 37,5 \\
\hline & 3 & 0 & 0,0 & 0 & 0,0 & 0 & 0,0 & 0 & 0,0 \\
\hline & 4 & 0 & 0,0 & 0 & 0,0 & 0 & 0,0 & 1 & 12,5 \\
\hline & 5 & 0 & 0,0 & 0 & 0,0 & $\overline{0}$ & 0,0 & 0 & 0,0 \\
\hline
\end{tabular}

$\mathrm{X}^{2(4)=} 4,276^{\mathrm{a}} ; \mathrm{p}<.05$

"Domestos okullara hijyen desteği vererek temizlik bilincine katkı sağlıyor" cümlesine 25-35 yaş aralığındaki kadınların 13'ü $(28,9)$ kesinlikle katılıyorum, 23'ü $(51,1 \%)$ katıliyorum, 5'i (11,1\%) kararsizım, 1'i (2,2\%) katılmıyorum, 3'ü (2,4\%) kesinlikle katılmiyorum; erkeklerin 10'u (33,3\%) kesinlikle kat1liyorum, 16's1 $(53,3 \%)$ katılıyorum, 2'si (6,7\%) kararsızım, 1'i (3,3\%) katılmıyorum, 1'i (3,3\%) de kesinlikle katılmıyorum yanıtını vermiştir. 35-45 yaş aralığındaki kadınların 20'si (39,2\%) kesinlikle katılıyorum, 23'ü (45,1\%) katılıyorum, 6'sı (11,8\%) kararsızım, 2'si (3,9\%) katılmıyorum yanıtını verirken kesinlikle katılmıyorum yanıtını veren katılımcı olmamıştır. Aynı yaş aralığındaki erkeklerin 6'sı (25,0\%) kesinlikle katıliyorum, 11 'i (45,8\%) kat1liyorum, 1'i (4,2\%) kararsızım, 3'ü (12,5\%) katılmıyorum, 3'ü (12,5\%) kesinlikle katılmıyorum yanıtını vermiştir. Domestos okullara hijyen desteği vererek temizlik bilincine katkı sağlıyor cümlesine katılım açısından kadınlarla erkekle arasında anlamlı bir fark vardır (p: ,370). Kadınlar erkeklere göre daha çok Domestos'un hijyen bilincine katkı sağladığını düşünmektedirler.
Tablo 15. "Domestos, Uygulamış Olduğu Sosyal Sorumluluk Projesiyle Topluma Yeterince Destek Olmuyor" Cümlesine Katılımcıların Verdiği Yanıtlar

\begin{tabular}{|c|c|c|c|c|c|c|c|c|c|}
\hline \multirow{3}{*}{$\begin{array}{c} \\
\text { G. } \\
\text { (TL) }\end{array}$} & & \multicolumn{4}{|c|}{ Kadın } & \multicolumn{4}{|c|}{ Erkek } \\
\hline & & \multicolumn{2}{|c|}{$25-35$} & \multicolumn{2}{|c|}{$35-45$} & \multicolumn{2}{|c|}{$25-35$} & \multicolumn{2}{|c|}{$35-45$} \\
\hline & & $\mathrm{N}$ & $\%$ & $\mathrm{~N}$ & $\%$ & $\overline{\mathrm{N}}$ & $\%$ & $\mathrm{~N}$ & $\%$ \\
\hline \multirow{5}{*}{1} & 1 & 0 & 0,0 & 2 & 40,0 & 0 & 0,0 & 0 & 0,0 \\
\hline & 2 & 0 & 0,0 & 1 & 20,0 & & 20,0 & 0 & 0,0 \\
\hline & 3 & 2 & 66,7 & 2 & 40,0 & 0 & 0,0 & 0 & 0,0 \\
\hline & 4 & 1 & 33,3 & 0 & 0,0 & 2 & 40,0 & 0 & 0,0 \\
\hline & 5 & 0 & 0,0 & 0 & 0,0 & 2 & 40,0 & 3 & 100 \\
\hline \multirow{5}{*}{2} & 1 & 0 & 0,0 & 1 & 14,3 & 0 & 0,0 & 0 & 0,0 \\
\hline & 2 & 1 & 33,3 & 1 & 14,3 & 1 & 9,1 & 0 & 0,0 \\
\hline & 3 & 1 & 33,3 & 4 & 57,1 & 2 & 18,2 & 2 & 28,6 \\
\hline & 4 & 1 & 33,3 & 1 & 14,3 & 5 & 45,5 & 0 & 0,0 \\
\hline & 5 & 0 & 0,0 & 0 & 0,0 & 2 & 27,3 & 5 & 71,4 \\
\hline \multirow{5}{*}{3} & 1 & 5 & 16,7 & 0 & 0,0 & 0 & 0,0 & 0 & 0,0 \\
\hline & 2 & 7 & 23,3 & 4 & 22,2 & 4 & 40,0 & 0 & 0,0 \\
\hline & 3 & 9 & 30,0 & 6 & 33,3 & 3 & 30,0 & 4 & 40,0 \\
\hline & 4 & 7 & 23,3 & 8 & 44,4 & 2 & 20,0 & 1 & 10,0 \\
\hline & 5 & 2 & 6,7 & 0 & 0,0 & 1 & 10,0 & 5 & 50,0 \\
\hline \multirow{5}{*}{4} & 1 & 0 & 0,0 & 0 & 0,0 & 0 & 0,0 & 0 & 0,0 \\
\hline & 2 & 1 & 11,1 & 7 & 43,8 & 0 & 0,0 & 0 & 0,0 \\
\hline & 3 & 5 & 55,6 & 4 & 25,0 & 4 & 100 & 0 & 0,0 \\
\hline & 4 & 3 & 33,3 & 3 & 18,8 & 0 & 0,0 & 0 & 0,0 \\
\hline & 5 & 0 & 0,0 & 2 & 12,5 & 0 & 0,0 & 1 & 100 \\
\hline \multirow{5}{*}{5} & 1 & 0 & 0,0 & 0 & 0,0 & 0 & 0,0 & 0 & 0,0 \\
\hline & 2 & 0 & 0,0 & 2 & 40,0 & 0 & 0,0 & 1 & 33,3 \\
\hline & 3 & 0 & 0,0 & 1 & 20,0 & 0 & 0,0 & 0 & 0,0 \\
\hline & 4 & 0 & 0,0 & 2 & 40,0 & 0 & 0,0 & 1 & 33,3 \\
\hline & 5 & 0 & 0,0 & 0 & 0,0 & 0 & 0,0 & 1 & 33,3 \\
\hline
\end{tabular}

$\mathrm{X}^{2(4)}=33,172^{\mathrm{a}} ; \mathrm{p}<.05$

Katılımciların "Domestos, uygulamış olduğu sosyal sorumluluk projesi ile topluma yeterince destek olmuyor" cümlesine verdikleri yanıtların dağılımına bakıldığında 25 35 yaş aralığındaki kadınların 5'inin (11,1\%) kesinlikle katıliyorum, 9'unun (20,0\%) katıliyorum, 17'sinin (37,8\%) kararsızım, 12'sinin (26,7\%) katılmıyorum, 2'sinin (4,4\%) ise kesinlikle katılmıyorum yanıtını verdikleri görülmektedir. Aynı yaş aralığındaki erkeklerin 6'sı (20,0\%) katılıyorum, 9'u (30,0\%) kararsızım, 9'u (30,0\%) katılmiyorum ve 6's1 (20,0\%) kesinlikle katılmiyorum yanıtını vermiştir. Kesinlikle katılıyorum yanıtını veren ise olmamıştır. 35-45 yaş aralığındaki kadınların 3'ü (5,9\%) kesinlikle katıliyorum, 15'i (10,9\%) kat1liyorum, 17'si $(33,3)$ kararsızım, 14'ü (27,5\%) katılmıyorum, 2'si (3,9\%) kesinlikle katılmıyorum; erkeklerin 1 ' $\mathrm{i}(4,2 \%)$ katılıyorum, 6's1 (25,0\%) kararsızım, 2'si (8,3\%) katılmıyorum, 15'i $(62,5 \%)$ kesinlikle katılmıyorum yanıtını verirken kesinlikle katılıyorum yanıtını veren olmamıştır. Ki kare testi sonuçlarına bakıldığında p: ,000 çıkmıştır. Dolayısıyla "Domestos, uygulamış olduğu sosyal sorumluluk projesi ile topluma yeterince destek olmuyor" cümlesine katılım açısından kadınlarla erkekler arasında anlamlı bir fark olduğu görülmektedir. Verilen toplam yanıtlara bakıldığında Domestos her ne kadar temizlik bilincine katkı sağlasa da topluma yeterince destek olma konusunda kadınların erkeklere göre daha olumsuz yönde yanıtlar verdikleri dikkat çekmektedir. 
Tablo 16. "Domestos, Yaptığı Proje ile Markaya Yönelmemi Sağlıyor” Cümlesine Katılımcıların Verdiği Yanıtlar

\begin{tabular}{|c|c|c|c|c|c|c|c|c|c|}
\hline \multirow{3}{*}{$\begin{array}{c} \\
\text { G. } \\
\text { (TL) }\end{array}$} & & \multicolumn{4}{|c|}{ Kadın } & \multicolumn{4}{|c|}{ Erkek } \\
\hline & & \multicolumn{2}{|c|}{$25-35$} & \multicolumn{2}{|c|}{$35-45$} & \multicolumn{2}{|c|}{$25-35$} & \multicolumn{2}{|c|}{$35-45$} \\
\hline & & $\mathrm{N}$ & $\%$ & $\mathrm{~N}$ & $\%$ & $\mathrm{~N}$ & $\%$ & $\mathrm{~N}$ & $\%$ \\
\hline \multirow{5}{*}{1} & 1 & 0 & 0,0 & 3 & 60,0 & 4 & 20,0 & 1 & 33,3 \\
\hline & 2 & 3 & 100 & 2 & 40,0 & 2 & 40,0 & 1 & 33,3 \\
\hline & 3 & 0 & 0,0 & 0 & 0,0 & 2 & 40,0 & 0 & 0,0 \\
\hline & 4 & 0 & 0,0 & 0 & 0,0 & 0 & 0,0 & 0 & 0,0 \\
\hline & 5 & 0 & 0,0 & 0 & 0,0 & 0 & 0,0 & 1 & 33,3 \\
\hline \multirow{5}{*}{2} & & 1 & 33,3 & 1 & 14,3 & 2 & 18,2 & 0 & 0,0 \\
\hline & 2 & 2 & 66,7 & 4 & 57,1 & 3 & 27,3 & 0 & 0,0 \\
\hline & 3 & 0 & 0,0 & 2 & 28,6 & 5 & 45,5 & 4 & 57,1 \\
\hline & 4 & 0 & 0,0 & 0 & 0,0 & 1 & 9,1 & 1 & 14,3 \\
\hline & 5 & 0 & 0,0 & 0 & 0,0 & 0 & 0,0 & 2 & 28,6 \\
\hline \multirow{5}{*}{3} & 1 & 4 & 13,3 & 2 & 11,1 & 1 & 10,0 & 2 & 20,0 \\
\hline & 2 & 11 & 36,7 & 7 & 38,9 & 6 & 60,0 & 5 & 50,0 \\
\hline & 3 & 5 & 16,7 & 6 & 33,3 & 2 & 20,0 & 2 & 20,0 \\
\hline & 4 & 10 & 33,3 & 1 & 5,6 & 1 & 10,0 & 0 & 0,0 \\
\hline & 5 & 0 & 0,0 & 2 & 11,1 & 0 & 0,0 & 1 & 10,0 \\
\hline \multirow{5}{*}{4} & 1 & 1 & 11,1 & 0 & 0,0 & 0 & 0,0 & 0 & 0,0 \\
\hline & 2 & 5 & 55,6 & 10 & 62,5 & 2 & 50,0 & 1 & 100 \\
\hline & 3 & 2 & 22,2 & 5 & 31,3 & 1 & 25,0 & 0 & 0,0 \\
\hline & 4 & 1 & 11,1 & 1 & 6,3 & 1 & 25,0 & $\overline{0}$ & 0,0 \\
\hline & 5 & 0 & 0,0 & 0 & 0,0 & 0 & 0,0 & 0 & 0,0 \\
\hline \multirow{5}{*}{5} & 1 & 0 & 0,0 & 3 & 60,0 & 0 & 0,0 & 0 & 0,0 \\
\hline & 2 & 0 & 0,0 & 2 & 40,0 & 0 & 0,0 & 1 & 33,3 \\
\hline & 3 & 0 & 0,0 & 0 & 0,0 & 0 & 0,0 & 1 & 33,3 \\
\hline & 4 & 0 & 0,0 & 0 & 0,0 & 0 & 0,0 & 0 & 0 \\
\hline & 5 & 0 & 0,0 & 0 & 0,0 & 0 & 0,0 & 1 & 33,3 \\
\hline
\end{tabular}

$\mathrm{X}^{2(4)=} 7,347^{\mathrm{a}} ; \mathrm{p}<.05$

"Domestos, yaptı̆̆ı proje ile markaya yönelmemi sağlıyor" cümlesine 25-35 yaş aralığındaki kadınların 6'sı (13,3\%) kesinlikle katıliyorum, 21'i (46,7\%) kat1lıyorum, 7'si $(15,6 \%)$ kararsızım, 11 'i $(24,4 \%)$ katılmıyorum; erkeklerin 4'ü (13,3\%) kesinlikle kat1liyorum, 13'ü (43,3\%) katıliyorum, 10’u (33,3\%) kararsızım, 3’ü (10,0\%) katılmıyorum yanıtını verirken, kesinlikle katılmıyorum yanıtını veren kadın ve erkek katılımcı olmamıştır. 35-45 yaş aralığındaki kadınların ise 9'u (17,6\%) kesinlikle katıliyorum, 25'i (49,0\%) katıliyorum, 13'ü (25,5\%) kararsızım, 2'si (3,9\%) katılmıyorum, 2'si (3,9\%) kesinlikle katılmiyorum; erkeklerin 3'ü (12,5\%) kesinlikle katıliyorum, 8'i (33,3\%) katıliyorum, 7'si (29,2\%) kararsızım, 1'i (4,2\%) katılmıyorum, 5'i (20,8\%) kesinlikle katılmıyorum yanıtını vermiştir. Yaptığı proje ile markaya yönelmeyi sağlama açısından kadınlarla erkekler arasında (p: ,119) anlamlı bir fark vardır. Verilen yanıtlardan kadınların projeye katkı sağlamak amacıyla markaya yönelimlerinin daha çok olduğu anlaşılmaktadır.
Tablo 17. "Bu Markayı Kullanmamda Projenin Bir Etkisi Yok" Cümlesine Katılımcıların Verdiği Yanıtlar

\begin{tabular}{|c|c|c|c|c|c|c|c|c|c|}
\hline \multirow{3}{*}{$\begin{array}{c} \\
\text { G. } \\
\text { (TL) }\end{array}$} & & \multicolumn{4}{|c|}{ Kadın } & \multicolumn{4}{|c|}{ Erkek } \\
\hline & & \multicolumn{2}{|c|}{$25-35$} & \multicolumn{2}{|c|}{$35-45$} & \multicolumn{2}{|c|}{$25-35$} & \multicolumn{2}{|c|}{$35-45$} \\
\hline & & $\mathrm{N}$ & $\%$ & $\mathrm{~N}$ & $\%$ & $\mathrm{~N}$ & $\%$ & $\mathrm{~N}$ & $\%$ \\
\hline \multirow{5}{*}{1} & 1 & 2 & 66,7 & 2 & 40,0 & 0 & 0,0 & 0 & 0,0 \\
\hline & 2 & 0 & 0,0 & 2 & 40,0 & 3 & 60,0 & 1 & 33,3 \\
\hline & 3 & 0 & 0,0 & 1 & 20,0 & 0 & 0,0 & 0 & 0,0 \\
\hline & 4 & 1 & 33,3 & 0 & 0,0 & 1 & 20,0 & 1 & 33,3 \\
\hline & 5 & 0 & 0,0 & 0 & 0,0 & 1 & 20,0 & 1 & 33,3 \\
\hline \multirow{5}{*}{2} & 1 & 1 & 33,3 & 0 & 0,0 & 2 & 18,2 & 0 & 0,0 \\
\hline & 2 & 1 & 33,3 & 0 & 0,0 & 2 & 18,2 & 3 & 42,9 \\
\hline & 3 & 1 & 33,3 & 2 & 28,6 & 1 & 9,1 & 0 & 0,0 \\
\hline & 4 & 0 & 0,0 & 5 & 71,4 & 3 & 27,3 & 1 & 14,3 \\
\hline & 5 & 0 & 0,0 & 0 & 0,0 & 3 & 27,3 & 3 & 42,9 \\
\hline \multirow{5}{*}{3} & 1 & 4 & 14,3 & 2 & 11,1 & 1 & 10,0 & 0 & 0,0 \\
\hline & 2 & 9 & 30,0 & 2 & 11,1 & 2 & 20,0 & 3 & 30,0 \\
\hline & 3 & 7 & 23,3 & 6 & 33,3 & 3 & 30,0 & 0 & 0,0 \\
\hline & 4 & 8 & 26,7 & 8 & 44,4 & 4 & 40,0 & 4 & 40,0 \\
\hline & 5 & 2 & 6,7 & 0 & 0,0 & 0 & 0,0 & 3 & 30,0 \\
\hline \multirow{5}{*}{4} & 1 & 1 & 11,1 & 0 & 0,0 & 0 & 0,0 & 0 & 0,0 \\
\hline & 2 & 1 & 11,1 & 1 & 6,3 & 1 & 25,0 & 0 & 0,0 \\
\hline & 3 & 7 & 77,8 & 7 & 43,8 & 0 & 0,0 & 0 & 0,0 \\
\hline & 4 & 0 & 0,0 & 8 & 50,0 & 2 & 50,0 & 0 & 0,0 \\
\hline & 5 & 0 & 0,0 & 0 & 0,0 & 1 & 25,0 & 1 & 100 \\
\hline \multirow{5}{*}{5} & 1 & 0 & 0,0 & 3 & 60,0 & 0 & 0,0 & 0 & 0,0 \\
\hline & 2 & 0 & 0,0 & 0 & 0,0 & 0 & 0,0 & 1 & 33,3 \\
\hline & 3 & 0 & 0,0 & 0 & 0,0 & 0 & 0,0 & 0 & 0,0 \\
\hline & 4 & 0 & 0,0 & 2 & 40,0 & 0 & 0,0 & 1 & 33,3 \\
\hline & 5 & 0 & 0,0 & 0 & 0,0 & 0 & 0,0 & 1 & 33,3 \\
\hline
\end{tabular}

$\mathrm{X}^{2(4)}=33,269^{\mathrm{a}} ; \mathrm{p}<.05$

"Bu markayı kullanmamda projenin etkisi yok cümlesine" 25-35 yaş aralığındaki kadınların 8'i (17,8\%) kesinlikle katıliyorum, 11'i $(24,4 \%)$ katıliyorum, 15'i (33,3\%) kararsızım, 9'u (20,0\%) katılmıyorum, 2'si (4,4\%) kesinlikle katılmıyorum; erkeklerin 3'(10,0\%), kesinlikle katıliyorum, 8'i (26,7\%) katıliyorum, 4'ü (13,3\%) kararsızım, 10'u (33,3\%) katılmıyorum, 5'i (16,7\%) kesinlikle katılmıyorum yanıtını vermiştir. 35-45 yaş aralığındaki kadınların ise 7'si $(13,7 \%)$ kesinlikle katıliyorum, 5'i (9,8\%) kat1liyorum, 16's1 (31,4\%) kararsızım, 23'ü $(45,1 \%)$ katılmıyorum yanıtını verirken kesinlikle katılmıyorum yanıtını veren olmamıștır. Erkeklerin 8'i (33,3\%) katılmiyorum, 7'si (29,2\%) katılmıyorum, 9'u (37,5\%) da kesinlikle katılmiyorum yanıtını vermiştir. Erkek katılımcılarda kesinlikle katılıyorum ve kararsızım yanıtını veren olmamıştır. Verilen yanıtlar değerlendirildiğinde kadınlarla erkekler arasında markaya yönelim konusunda projenin etkisine ilişkin anlamlı bir fark vardır (p: ,000). Verilen yanıtlardan kadınların projeden dolayı markaya daha çok yöneldikleri sonucunu çıkarmak mümkündür. 
Tablo 18. "Ürün Satışlarının Okullara Bağış İçin Kullanıldığına İnanmıyorum" Cümlesine Katılımcıların Verdiği Yanıtlar

\begin{tabular}{|c|c|c|c|c|c|c|c|c|c|}
\hline \multirow{3}{*}{$\begin{array}{c} \\
\text { G. } \\
\text { (TL) }\end{array}$} & & \multicolumn{4}{|c|}{ Kadın } & \multicolumn{4}{|c|}{ Erkek } \\
\hline & & \multicolumn{2}{|c|}{$25-35$} & \multicolumn{2}{|c|}{$35-45$} & \multicolumn{2}{|c|}{$25-35$} & \multicolumn{2}{|c|}{$35-45$} \\
\hline & & $\mathrm{N}$ & $\%$ & $\mathrm{~N}$ & $\%$ & $\mathrm{~N}$ & $\%$ & $\mathrm{~N}$ & $\%$ \\
\hline \multirow{5}{*}{1} & 1 & 0 & 0,0 & 0 & 0,0 & 0 & 0,0 & 0 & 0,0 \\
\hline & 2 & 0 & 0,0 & 2 & 40,0 & & 20,0 & 0 & 0,0 \\
\hline & 3 & 0 & 0,0 & 2 & 40,0 & 1 & 20,0 & 1 & 33,3 \\
\hline & 4 & 3 & 100 & 1 & 20,0 & 2 & 40,0 & 2 & 66,7 \\
\hline & 5 & 0 & 0,0 & 0 & 0,0 & & 20,0 & 0 & 0,0 \\
\hline \multirow{5}{*}{2} & & 1 & 33,3 & 1 & 14,3 & 1 & 9,1 & 1 & 14,3 \\
\hline & 2 & 0 & 0,0 & 0 & 0,0 & 1 & 9,1 & 0 & 0,0 \\
\hline & 3 & 1 & 33,3 & 3 & 42,9 & 5 & 45,5 & 1 & 14,3 \\
\hline & 4 & 0 & 0,0 & 0 & 0,0 & 2 & 18,2 & 2 & 28,6 \\
\hline & 5 & 1 & 33,3 & 3 & 42,9 & 2 & 18,2 & 3 & 42,9 \\
\hline \multirow{5}{*}{3} & 1 & 1 & 3,3 & 0 & 0,0 & 2 & 20,0 & 1 & 10,0 \\
\hline & 2 & 0 & 0,0 & 2 & 11,1 & 1 & 10,0 & 0 & 0,0 \\
\hline & 3 & 9 & 30,0 & 8 & 44,4 & 3 & 30,0 & 3 & 30,0 \\
\hline & 4 & 17 & 56,7 & 5 & 27,8 & 1 & 10,0 & 2 & 20,0 \\
\hline & 5 & 3 & 10,0 & 3 & 16,7 & 3 & 30,0 & 4 & 40,0 \\
\hline \multirow{5}{*}{4} & 1 & 1 & 11,1 & 0 & 0,0 & 0 & 0,0 & 0 & 0,0 \\
\hline & 2 & 0 & 0,0 & 0 & 0,0 & 0 & 0,0 & 0 & 0,0 \\
\hline & 3 & 5 & 55,6 & 10 & 62,5 & 1 & 25,0 & 0 & 0,0 \\
\hline & 4 & 1 & 11,1 & 4 & 25,0 & 1 & 25,0 & $\overline{0}$ & 0,0 \\
\hline & 5 & 2 & 22,2 & 2 & 12,5 & 2 & 50,0 & 1 & 100 \\
\hline \multirow{5}{*}{5} & 1 & 0 & 0,0 & 0 & 0,0 & 0 & 0,0 & 1 & 12,5 \\
\hline & 2 & 0 & 0,0 & 1 & 20,0 & 0 & 0,0 & 1 & 12,5 \\
\hline & 3 & 0 & 0,0 & 2 & 40,0 & 0 & 0,0 & 4 & 50,0 \\
\hline & 4 & 0 & 0,0 & 1 & 20,0 & 0 & 0,0 & 1 & 12,5 \\
\hline & 5 & 0 & 0,0 & 1 & 20,0 & 0 & 0,0 & 1 & 12,5 \\
\hline
\end{tabular}

$\mathrm{X}^{2(4)}=8,186^{\mathrm{a}} ; \mathrm{p}<.05$

"Ürün satışlarının okullara bağış için kullanıldığına inanmıyorum" cümlesine 25-35 yaş aralığındaki kadınların 3'ü (6,7\%) kesinlikle katılıyorum, 15'i (33,3\%) kararsızım, 21'i (46,7\%) katılmiyorum, 6's1 (13,3\%) kesinlikle katılmıyorum; erkeklerin 3'ü $(10,0)$ kesinlikle katılıyorum, 3'ü (10,0) katıliyorum, 10'u (33,3\%) kararsızım, 6’s1 (20,0\%) katılmıyorum, 8'i (26,7\%) kesinlikle katılmıyorum yanıtını vermiştir. 35-45 yaş aralığındaki kadınların 12 'i $(2,0 \%)$ kesinlikle katıliyorum, 5'i (9,8\%) katılıyorum, 25'i (49,0\%) kararsızım, 11'i (21,6\%) katılmıyorum, 9'u $(17,6 \%)$ kesinlikle katılmiyorum, erkeklerin 3'ü (12,5\%) kesinlikle katılmıyorum, 7'si (29,2\%) kararsızım, 6's1 (25,0\%) katılmıyorum, 8'i (33,3\%) kesinlikle katılmıyorum yanıtını vermiştir. Ki kare testi sonucunda p: ,085 çıkmıştır. Dolayısıyla kadınlarla erkekler arasında "ürün satışlarının okullara bağış için kullanıldığına inanmıyorum” cümlesine verilen yanıtlar bakımından anlamlı bir fark vardır. Kadınlar erkekler göre ürün satışlarının okullara bağış için kullanıldığına daha çok inanmaktadırlar.
Tablo 19. "İhtiyacım Olmasa Da Destek İçin Domestos Alırım" Cümlesine Katılımcıların Verdiği Yanıtlar

\begin{tabular}{|c|c|c|c|c|c|c|c|c|c|}
\hline \multirow{3}{*}{$\begin{array}{c} \\
\text { G. } \\
\text { (TL) }\end{array}$} & & \multicolumn{4}{|c|}{ Kadın } & \multicolumn{4}{|c|}{ Erkek } \\
\hline & & \multicolumn{2}{|c|}{$25-35$} & \multicolumn{2}{|c|}{$35-45$} & \multicolumn{2}{|c|}{$25-35$} & \multicolumn{2}{|c|}{$35-45$} \\
\hline & & $\mathrm{N}$ & $\%$ & $\mathrm{~N}$ & $\%$ & $\mathrm{~N}$ & $\%$ & $\mathrm{~N}$ & $\%$ \\
\hline \multirow{5}{*}{1} & 1 & 1 & 33,3 & 0 & 0,0 & 0 & 0,0 & 0 & 0,0 \\
\hline & 2 & 2 & 66,7 & 3 & 60,0 & 3 & 60,0 & 0 & 0,0 \\
\hline & 3 & 0 & 0,0 & 0 & 0,0 & 1 & 20,0 & 0 & 0,0 \\
\hline & 4 & 0 & 0,0 & 2 & 40,0 & 1 & 20,0 & 0 & 0,0 \\
\hline & 5 & 0 & 0,0 & 0 & 0,0 & 0 & 0,0 & 3 & 100 \\
\hline \multirow{5}{*}{2} & 1 & 0 & 0,0 & 2 & 28,6 & 2 & 18,2 & 0 & 0,0 \\
\hline & 2 & 0 & 0,0 & 4 & 57,1 & 2 & 18,2 & 2 & 28,6 \\
\hline & 3 & 3 & 100 & 1 & 14,3 & 2 & 18,2 & 0 & 0,0 \\
\hline & 4 & 0 & 0,0 & 0 & 0,0 & 3 & 27,3 & 0 & 0,0 \\
\hline & 5 & 0 & 0,0 & 0 & 0,0 & 2 & 18,2 & 5 & 71,4 \\
\hline \multirow{5}{*}{3} & 1 & 5 & 16,7 & 4 & 22,2 & 1 & 10,0 & 1 & 10,0 \\
\hline & 2 & 15 & 50,0 & 8 & 44,4 & 1 & 10,0 & 2 & 20,0 \\
\hline & 3 & 7 & 23,3 & 1 & 5,6 & 3 & 30,0 & 2 & 20,0 \\
\hline & 4 & 3 & 10,0 & 1 & 5,6 & 3 & 30,0 & 0 & 0,0 \\
\hline & 5 & 0 & 0,0 & 4 & 22,2 & 2 & 20,0 & 5 & 50,0 \\
\hline \multirow{5}{*}{4} & 1 & 1 & 11,1 & 2 & 12,5 & 0 & 0,0 & 1 & 100 \\
\hline & 2 & 4 & 44,4 & 3 & 18,8 & 1 & 25,0 & 0 & 0,0 \\
\hline & 3 & 2 & 22,2 & 3 & 18,8 & 1 & 25,0 & 0 & 0,0 \\
\hline & 4 & 1 & 11,1 & 5 & 31,3 & 1 & 25,0 & 0 & 0,0 \\
\hline & 5 & 1 & 11,1 & 3 & 18,8 & 1 & 25,0 & 0 & 0,0 \\
\hline \multirow{5}{*}{5} & 1 & 0 & 0,0 & 0 & 0,0 & 0 & 0,0 & 0 & 0,0 \\
\hline & 2 & 0 & 0,0 & 0 & 0,0 & 0 & 0,0 & 0 & 0,0 \\
\hline & 3 & 0 & 0,0 & 3 & 60,0 & 0 & 0,0 & 0 & 0,0 \\
\hline & 4 & 0 & 0,0 & 0 & 0,0 & 0 & 0,0 & 0 & 0,0 \\
\hline & 5 & 0 & 0,0 & 2 & 40,0 & 0 & 0,0 & 3 & 100 \\
\hline
\end{tabular}

$\mathrm{X}^{2(4)=} 19,310^{\mathrm{a}} ; \mathrm{p}<.05$

"İhtiyacım olmasa da destek için Domestos alırım" cümlesine 25-35 yaş aralığındaki kadınların 7'si (15,6\%) kesinlikle katılıyorum, 21'i (46,7\%) katılıyorum, 12'si (26,7\%) kararsızım, 4'ü (8,9\%) katılmıyorum, 1'i $(2,2 \%)$ kesinlikle katılmiyorum; erkeklerin 3'ü (10,0\%) kesinlikle katıliyorum, 7'si (23,3\%) kat1liyorum, 7'si (23,3\%) kararsızım, 8'i (26,7\%) katılmıyorum, 5'i (16,7\%) kesinlikle katılmıyorum yanıtını vermiştir. 35-45 yaş aralığındaki kadınların ise 8 'i $(15,7 \%)$ kesinlikle katıliyorum, 18 'i (35,3\%) katıliyorum, 8'i (15,7\%) kararsızım, 8'i (15,7\%) katılmıyorum, 9'u (17,6\%) kesinlikle katılmıyorum; erkeklerin 2'si (8,3\%) kesinlikle katıliyorum, 4'ü (16,7\%) kat1liyorum, 2'si (8,3\%) kararsızım, 16'sı (66,7\%) kesinlikle katılmıyorum yanıtı verirken, katılmıyorum yanıtını veren olmamıştır. Genel olarak söylemek gerekirse kadınların ihtiyaçları olmadığı halde kampanyaya destek için ürünü satın almaya erkeklere göre daha yatkın oldukları görülmektedir. Ki kare testi sonucunda da erkeklerle kadınlar arasında destek için ürünü satın alırım cümlesine verilen yanıtlar açısından anlamlı bir fark vardır (p: ,001). Kadınlar, kampanyaya destek için markanın ürünlerini erkeklere göre daha çok satın alma eğilimindedirler. 
Tablo 20. "Ürün Fiyatı Projeye Destek Olurken Önemli Değildir" Cümlesine Verilen Yanitlar

\begin{tabular}{|c|c|c|c|c|c|c|c|c|c|}
\hline \multirow{3}{*}{$\begin{array}{c} \\
\text { G. } \\
(\mathrm{TL})\end{array}$} & & \multicolumn{4}{|c|}{ Kadın } & \multicolumn{4}{|c|}{ Erkek } \\
\hline & & \multicolumn{2}{|c|}{$25-35$} & \multicolumn{2}{|c|}{$35-45$} & \multicolumn{2}{|c|}{$25-35$} & \multicolumn{2}{|c|}{$35-45$} \\
\hline & & $\mathrm{N}$ & $\%$ & $\mathrm{~N}$ & $\%$ & $\mathrm{~N}$ & $\%$ & $\mathrm{~N}$ & $\%$ \\
\hline \multirow{5}{*}{1} & 1 & 1 & 33,3 & 0 & 0,0 & 0 & 0,0 & 0 & 0,0 \\
\hline & 2 & 1 & 33,3 & 1 & 20,0 & 0 & 0,0 & 0 & 0,0 \\
\hline & 3 & 1 & 33,3 & 2 & 40,0 & 2 & 40,0 & 0 & 0,0 \\
\hline & 4 & 0 & 0,0 & 1 & 20,0 & 2 & 40,0 & 3 & 100 \\
\hline & 5 & 0 & 0,0 & 1 & 20,0 & 1 & 20,0 & 0 & 0,0 \\
\hline \multirow{5}{*}{2} & 1 & 1 & 33,3 & 0 & 0,0 & 1 & 9,1 & 0 & 0,0 \\
\hline & 2 & 0 & 0,0 & 3 & 42,9 & 1 & 9,1 & 1 & 14,3 \\
\hline & 3 & 1 & 33,3 & 3 & 42,9 & 3 & 27,3 & 2 & 28,6 \\
\hline & 4 & 1 & 33,3 & 1 & 14,3 & 3 & 27,3 & 3 & 42,9 \\
\hline & 5 & 0 & 0,0 & 0 & 0,0 & 3 & 27,3 & 1 & 14,3 \\
\hline \multirow{5}{*}{3} & 1 & 3 & 10,0 & 0 & 0,0 & 0 & 0,0 & 0 & 0,0 \\
\hline & 2 & 7 & 23,3 & 5 & 27,8 & 3 & 30,0 & 0 & 0,0 \\
\hline & 3 & 10 & 33,3 & 4 & 22,2 & 4 & 40,0 & 1 & 10,0 \\
\hline & 4 & 10 & 33,3 & 3 & 16,7 & 2 & 20,0 & 7 & 70,0 \\
\hline & 5 & 0 & 0,0 & 6 & 33,3 & 1 & 10,0 & 2 & 20,0 \\
\hline \multirow{5}{*}{4} & 1 & 1 & 11,1 & 1 & 6,3 & 0 & 0,0 & 0 & 0,0 \\
\hline & 2 & 2 & 22,2 & 2 & 18,8 & 1 & 25,5 & 0 & 0,0 \\
\hline & 3 & 4 & 44,4 & 8 & 50,0 & 1 & 25,5 & 0 & 0,0 \\
\hline & 4 & 2 & 22,2 & 3 & 18,8 & 1 & 25,5 & 1 & 100 \\
\hline & 5 & 0 & 0,0 & 1 & 6,3 & 1 & 25,5 & 0 & 0,0 \\
\hline \multirow{5}{*}{5} & 1 & 0 & 0,0 & 0 & 0,0 & 0 & 0,0 & 0 & 0,0 \\
\hline & 2 & 0 & 0,0 & 0 & 0,0 & 0 & 0,0 & 0 & 0,0 \\
\hline & 3 & 0 & 0,0 & 1 & 33,3 & 0 & 0,0 & 3 & 37,5 \\
\hline & 4 & 0 & 0,0 & 2 & 66,7 & 0 & 0,0 & 5 & 63,5 \\
\hline & 5 & 0 & 0,0 & 0 & 0,0 & 0 & 0,0 & 0 & 0,0 \\
\hline
\end{tabular}

$\mathrm{X}^{2(4)=} 11,872^{\mathrm{a}} ; \mathrm{p}<.05$

"Ürün fiyatı projeye destek olurken önemli değildir" cümlesine 25-35 yaş aralığındaki kadınların 6'sı (13,3\%) kesinlikle katıliyorum, 10'u (22,2\%) katıliyorum, 16's1 (35,6\%) kararsızım, 13'ü $(28,9 \%)$ katılmıyorum yanıtını verirken kesinlikle katılmıyorum yanıtını veren olmamıştır. Aynı yaş aralığındaki erkeklerin 1'i (3,3\%) kesinlikle katıliyorum, 5'i (16,7\%) katıliyorum, 10'u (33,3\%) kararsızım, 8'i (26,7\%) katılmıyorum, 6's1 (20,0\%) kesinlikle katılmıyorum yanıtını vermiştir. 35-35 yaş aralığındaki kadınların ise 1 ' $i \quad(2,0 \%)$ kesinlikle katıliyorum, 12'si (23,5\%) katıliyorum, 19'u (37,3\%) kararsızım, 11'i (21,6\%) katılmıyorum, 8'i (15,7\%) kesinlikle katılmıyorum; erkeklerin 1'i (4,2\%) katılıyorum, 4'ü (16,7\%) kararsızım, 16'sı (66,7\%) katılmıyorum, 8'i $(12,5 \%)$ kesinlikle katılmıyorum yanıtını vermiştir. Ürün fiyatı projeye destek olurken önemli değildir cümlesine verilen yanıtlarda kadınlarla erkekler arasında anlamlı bir fark vardır (p: ,004). Kadınlar, erkeklere göre ürün fiyatının projeye destek olma noktasında önemli olmadığını düşünmektedirler.
Tablo 21. "Domestos Markası Yeterince Sosyal Sorumluluk Projesi Yapmiyor" Cümlesine Verilen Yanıtlar

\begin{tabular}{|c|c|c|c|c|c|c|c|c|c|}
\hline \multirow{3}{*}{$\begin{array}{c} \\
\text { G. } \\
\text { (TL) }\end{array}$} & & \multicolumn{4}{|c|}{ Kadın } & \multicolumn{4}{|c|}{ Erkek } \\
\hline & & \multicolumn{2}{|c|}{$25-35$} & \multicolumn{2}{|c|}{$35-45$} & \multicolumn{2}{|c|}{$25-35$} & \multicolumn{2}{|c|}{$35-45$} \\
\hline & & $\mathrm{N}$ & $\%$ & $\mathrm{~N}$ & $\%$ & $\mathrm{~N}$ & $\%$ & $\mathrm{~N}$ & $\%$ \\
\hline \multirow{5}{*}{1} & 1 & 0 & 0,0 & 0 & 0,0 & 0 & 0,0 & 0 & 0,0 \\
\hline & 2 & 2 & 66,7 & 1 & 20,0 & 0 & 0,0 & 1 & 33,3 \\
\hline & 3 & 1 & 33,3 & 3 & 60,0 & 2 & 40,0 & 1 & 0,0 \\
\hline & 4 & 0 & 0,0 & 1 & 20,0 & 2 & 40,0 & 1 & 33,3 \\
\hline & $J$ & 0 & 0,0 & 0 & 0,0 & 1 & 20,0 & 0 & 33,3 \\
\hline \multirow{5}{*}{2} & & 0 & 0,0 & 0 & 0,0 & 0 & 0,0 & 0 & 0,0 \\
\hline & 2 & 1 & 33,3 & 1 & 14,3 & 2 & 18,2 & 2 & 28,6 \\
\hline & 3 & 1 & 33,3 & 3 & 42,9 & 5 & 45,5 & 4 & 57,1 \\
\hline & 4 & 1 & 33,3 & 3 & 42,9 & 1 & 9,1 & 1 & 14,3 \\
\hline & 5 & 0 & 0,0 & 0 & 0,0 & 3 & 27,3 & 0 & 0,0 \\
\hline \multirow{5}{*}{3} & 1 & 2 & 6,7 & 0 & 0,0 & 0 & 0,0 & 0 & 0,0 \\
\hline & 2 & 8 & 26,7 & 3 & 16,7 & 1 & 10,0 & 3 & 30,0 \\
\hline & 3 & 10 & 33,3 & 10 & 55,6 & 6 & 60,0 & 3 & 30,0 \\
\hline & 4 & 9 & 30,0 & 1 & 5,6 & 3 & 30,0 & 1 & 10,0 \\
\hline & 5 & 1 & 3,3 & 4 & 22,2 & 0 & 0,0 & 3 & 30,0 \\
\hline \multirow{5}{*}{4} & 1 & 0 & 0,0 & 0 & 0,0 & 0 & 0,0 & 0 & 0,0 \\
\hline & 2 & 4 & 44,4 & 3 & 18,8 & 0 & 0,0 & 1 & 100 \\
\hline & 3 & 3 & 33,3 & 9 & 56,3 & 1 & 25,0 & 0 & 0,0 \\
\hline & 4 & 1 & 11,1 & 3 & 18,8 & 3 & 75,0 & 0 & 0,0 \\
\hline & 5 & 1 & 11,1 & 1 & 6,3 & 0 & 0,0 & 0 & 0,0 \\
\hline \multirow{5}{*}{5} & 1 & 0 & 0,0 & 0 & 0,0 & 0 & 0,0 & 0 & 0,0 \\
\hline & 2 & 0 & 0,0 & 3 & 60,0 & 0 & 0,0 & 0 & 0,0 \\
\hline & 3 & 0 & 0,0 & 1 & 20,0 & 0 & 0,0 & 2 & 66,7 \\
\hline & 4 & 0 & 0,0 & 0 & 0,0 & 0 & 0,0 & 0 & 0,0 \\
\hline & 5 & 0 & 0,0 & 1 & 20,0 & 0 & 0,0 & 1 & 33,3 \\
\hline
\end{tabular}

$\mathrm{X}^{2(4)}=4,973^{\mathrm{a}} ; \mathrm{p}<.05$

"Domestos markası yeterince sosyal sorumluluk projesi yapmıyor" cümlesine 25-35 yaş aralığındaki kadınların 2'si $(4,4 \%)$ kesinlikle katılıyorum, 15'i (33,3\%) katılıyorum, 15'i (33,3\%) kararsızım, 11'i (24,4\%) katılmıyorum, 2'si $(4,4 \%)$ kesinlikle katılmiyorum; erkeklerin 3’ü (10,0\%) katıliyorum, 14'ü (46,7\%) kararsızım, 9'u (30,0\%) katılmıyorum, 4'ü (13,3\%) kesinlikle katılmıyorum yanıtını vermiştir. 35-45 yaş aralığındaki kadınların ise 11 '’ $\mathrm{i}(21,6 \%)$ katılıyorum, 26's1 (51,0\%) kararsızım, 8'i (15,7\%) katılmiyorum, 6's1 (11,8\%) kesinlikle katılmiyorum; erkeklerin 6's1 (25,0\%) katıliyorum, 10'u (41,7\%) kararsızım, 3'ü (12,5\%) katılmıyorum, 5'i (20,8\%) kesinlikle katılmıyorum yanıtını vermiştir. Kesinlikle katıliyorum yanıtını veren kadın ve erkek katılımcı olmamıștır. Ki kare testi sonucuna göre kadınlar ve erkekler arasinda Domestos'un yeterince sosyal sorumluluk projesi yapmadığına ilişkin verilen yanıtlarda kadınlar ve erkekler arasında anlamlı bir fark vardır (p: ,290). Kadınlar erkeklere göre Domestos'un yeterince kampanya yapmadığını düşünmektedir. 
Tablo 22. "Marka Tercihimde Sosyal Sorumluluk Projesi Yapması Benim İçin Önemli Değildir" Cümlesine Verilen Yanitlar

\begin{tabular}{|c|c|c|c|c|c|c|c|c|c|}
\hline \multirow{3}{*}{$\begin{array}{c} \\
\text { G. } \\
(\mathrm{TL})\end{array}$} & & \multicolumn{4}{|c|}{ Kadın } & \multicolumn{4}{|c|}{ Erkek } \\
\hline & & \multicolumn{2}{|c|}{$25-35$} & \multicolumn{2}{|c|}{$35-45$} & \multicolumn{2}{|c|}{$25-35$} & \multicolumn{2}{|c|}{$35-45$} \\
\hline & & $\mathrm{N}$ & $\%$ & $\mathrm{~N}$ & $\%$ & $\mathrm{~N}$ & $\%$ & $\mathrm{~N}$ & $\%$ \\
\hline \multirow{5}{*}{1} & 1 & 0 & 0,0 & 0 & 0,0 & 1 & 20,0 & 0 & 0,0 \\
\hline & 2 & 0 & 0,0 & 0 & 0,0 & 1 & 20,0 & 2 & 66,7 \\
\hline & 3 & 0 & 0,0 & 1 & 20,0 & 0 & 0,0 & 1 & 33,3 \\
\hline & 4 & 2 & 66,7 & 3 & 60,0 & 3 & 60,0 & 0 & 0,0 \\
\hline & 5 & 1 & 33,3 & 1 & 20,0 & 0 & 0,0 & 0 & 0,0 \\
\hline \multirow{5}{*}{2} & 1 & 0 & 0,0 & 0 & 0,0 & 2 & 18,2 & 2 & 28,6 \\
\hline & 2 & 2 & 66,7 & 1 & 14,3 & 1 & 9,1 & 0 & 0,0 \\
\hline & 3 & 1 & 33,3 & 1 & 14,3 & 5 & 45,5 & 0 & 0,0 \\
\hline & 4 & 0 & 0,0 & 5 & 71,4 & 3 & 27,3 & 3 & 42,9 \\
\hline & 5 & 0 & 0,0 & 0 & 0,0 & 0 & 0,0 & 2 & 28,6 \\
\hline \multirow{5}{*}{3} & 1 & 4 & 13,8 & 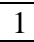 & 5,6 & 1 & 10,0 & 3 & 30,0 \\
\hline & 2 & 1 & 3,4 & 2 & 11,1 & 4 & 40,0 & 2 & 20,0 \\
\hline & 3 & 6 & 20,7 & 4 & 22,2 & 2 & 20,0 & 1 & 10,0 \\
\hline & 4 & 12 & 10,4 & 8 & 44,4 & 2 & 20,0 & 2 & 20,0 \\
\hline & 5 & 6 & 20,7 & 3 & 16,7 & 1 & 10,0 & 2 & 20,0 \\
\hline \multirow{5}{*}{4} & 1 & 0 & 0,0 & 3 & 18,8 & 1 & 25,0 & 0 & 0,0 \\
\hline & 2 & 3 & 33,3 & 3 & 18,8 & 1 & 25,0 & 0 & 0,0 \\
\hline & 3 & 1 & 11,1 & 4 & 25,0 & 0 & 0,0 & 0 & 0,0 \\
\hline & 4 & 4 & 44,4 & 3 & 18,8 & 0 & 25,0 & 1 & 100 \\
\hline & 5 & 1 & 11,1 & 3 & 18,8 & 1 & 25,0 & 0 & 0,0 \\
\hline \multirow{5}{*}{5} & 1 & 0 & 0,0 & 0 & 0,0 & 0 & 0,0 & 0 & 0,0 \\
\hline & 2 & 0 & 0,0 & 0 & 0,0 & 0 & 0,0 & 1 & 12,5 \\
\hline & 3 & 0 & 0,0 & 1 & 33,3 & 0 & 0,0 & 3 & 37,5 \\
\hline & 4 & 0 & 0,0 & 2 & 66,7 & 0 & 0,0 & 4 & 50,0 \\
\hline & 5 & 0 & 0,0 & 0 & 0,0 & 0 & 0,0 & 0 & 0,0 \\
\hline
\end{tabular}

$\mathrm{X}^{2(4)=} 5,345^{\mathrm{a}} ; \mathrm{p}<.05$

"Marka tercihimde sosyal sorumluluk projesi yapması benim için önemli değildir” cümlesine 25-35 yaş aralığındaki kadınların 4'ü $(9,1 \%)$ kesinlikle katılıyorum, 6's1 (13,6\%) katıliyorum, 8'i (18,2\%) kararsızım, 18'i $(40,9 \%) \quad$ katılmiyorum, 8 'i $\quad(18,2 \%) \quad$ kesinlikle katılmiyorum; erkeklerin 5'i $\quad(16,7 \%)$ kesinlikle katıliyorum, 7'si (23,3\%) katıliyorum, 7'si (23,3\%) kararsızım, 9'u (30,0\%) katılmıyorum, 2'si $(6,7)$ kesinlikle katılmıyorum yanıtını vermiştir. 35-45 yaş aralığındaki kadınların ise 4'ü (7,8\%) kesinlikle katılıyorum, 7'si $(13,7 \%)$ kat1lyorum, 12'si (23,5\%) kararsızım, 21'i $(41,2 \%) \quad$ katılmiyorum, 7'si $(13,7 \%) \quad$ kesinlikle katılmıyorum; erkeklerin 6'i $(20,8 \%)$ kesinlikle katıliyorum, 4'ü $(16,7 \%)$ kat1liyorum, 3'ü $(12,5 \%)$ kararsızım, 8'i (33,3\%) katılmıyorum, 4'ü (16,7\%) kesinlikle katılmıyorum yanıtını vermiştir. Marka tercihinde sosyal sorumluluk projesi yapması benim için önemli değildir cümlesine verilen yanıtlar açısından kadınlarla erkekler arasında anlamlı fark vardır (p: ,254). Kadınların marka tercihlerinde markanın yaptığı sosyal sorumluluk projelerinin etkili olduğunu söylemek mümkündür.

\section{Sonuc}

İşletmelerin halkla ilişkiler faaliyetleri kapsamında sosyal sorumluluk projelerinin kurumsal marka süreçlerine etkisi çalışması kapsamında müşterilerin, markaların sosyal sorumluluk projelerine bakış açılarını belirlemeye yönelik anket hazırlanmıştır. $\mathrm{Bu}$ anket çalışması Domestos markasının okullara bağış desteği yapılan sosyal sorumluluk çalışması üzerinden yapılmıştır. Ankete 25-45 yaș aralığında 45 kadın, 30 erkek; $35-45$ yaş aralığında ise 51 kadın, 24 erkek olmak üzere toplam 150 kişi katılmıştır.

Anket sonuçları değerlendirildiğinde katılımcıların sosyal sorumluluk projelerine büyük oranda önem verdikleri, marka tercihinde sosyal sorumluluk projelerini göz önünde bulundurdukları görülmüştür. Sosyal sorumluluk projelerinin marka imajını etkileyeceğini düşünen katılımcıların büyük çoğunluğunun Domestos'un okullara bağış sosyal sorumluluk projesinden haberdar oldukları sonucuna varılmıştır.

Domestos markası bu sosyal çalışma ile topluma hayırsever bir marka olduğunu, toplumun çıkarlarına ve yararına yönelik çalışmalar yaptığını göstermektedir. Bu noktada Domestos markasının yaptığı sosyal sorumluluk çalışması stratejik hayırseverlik alanına girmektedir. Domestos markası sosyal sorumluluk çalışması üzerinden hem okullara deterjan bağışına destek olmakta hem de ürün satışlarından kendi ekonomisine katkı sağlamaktadır. Markanın bu çalışmayla birlikte genel kitlenin yanı sıra asıl hedef kitlesi velilerdir. Çünkü veli demek ev, aile, kadın üçgenini de oluşturmaktadır. Velilerin çocuklarının hijyen durumu yüksek olan okullarda yetişmesi isteği bu markayı tercih etme duygusunu pekiştirmektedir. Böylece marka hem mükemmel hem de faydacı temizlik ürünü markası olarak algı oluşturmaktadır.

Elde edilen veriler incelendiğinde katılımcıların Domestos markasının yaptığı okullara bağış kampanyasını beğendiği, markanın bu kampanya ile temizlik bilincine katkı sağladığını, fakat markanın genel anlamda topluma karşı çok fazla sosyal sorumluluk çalışması yapmadığını düşündükleri sonucuna varılmıştır. Bu bize markanın toplumda daha çok temizlik ürünü olarak var olduğunu, toplumun gözünde farklı bir imaj yaratmadığını göstermektedir. Aynı zamanda katılımcılar markanın yaptığı proje ile ilgili olumlu düşüncelere sahip olsalar da ürün satışlarının okullara bağış için kullanıldığına inanma noktasında kararsız olduklarını belirtmişlerdir. Yapılan bu sosyal sorumluluk projesinde okulların baz alınması ve hijyene önem ve destek verilmesi marka üzerinde olumlu tutumları arttırmış ve toplum tarafindan beğeni kazandırmıştır. Ancak katılımcıların bağışların gerekli yerlere ulaştırılması konusunda şüpheli oldukları izlenimine varılmıştır. Bu da Domestos markasının topluma yeterince güven vermediğini göstermektedir. Markanın ürünü ne kadar iyi olursa olsun toplumun bağışların gerekli yerlere ulaştırılması konusunda genel olarak olumsuz düşündüğü görülmüştür. Bu noktada Domestos markasının da tam olarak güven yaratmadığı sonucuna varılmıştır. Dolayısıyla markanın sosyal sorumluluk projelerine daha çok ağırlık vermesi ve marka imajına olan bu yöndeki olumsuz bakışı kırması gerekmektedir. Öyle ki daha önce de belirtildiği gibi katılımcılar Domestos'un yeterince sosyal sorumluluk projesi yapmadığını düşünmektedir. Katılımcıların genel yanıtlarına bakıldığı zaman Domestos markasının taban kullanıcısının olduğu ve sosyal sorumluluk çalışmaları yapılmasa dahi bu markayı tercih eden markaya karşı bağlı bir tüketici gurubunun olduğu görülmektedir. Bu detay Domestos markasının belirli bir tüketici kitlesinin olduğunu ve marka bağlılığı yarattığını göstermektedir. Her ne kadar temizlik ürünleri bağlamında tercih edilen bir ürün olsa da markanın henüz toplumun gözünde duyarlı marka imajını yaratamadığı görülmektedir. 
Bir markanın sosyal sorumluluk başlı̆̆ı altında toplumu kazanmak gibi bir hedefi varsa uzun soluklu çalışmalar ve ses getiren stratejiler geliştirmesi gerekmektedir. Yapılan çalışmaların akılda kalıcılığının belirli zamanlarda gerekli medya araçları da kullanılarak pekiştirilmesi, özel gün ve zamanlarda da marka duyarlılığının gösterilmesi markanın toplumun beğenisini daha çok kazanmasını sağlayacaktır. Toplum; vicdana, yardımlaşmaya, sevgiye, duyarlılığa seslenen markalara karşı daha pozitif yaklaşmaktadır. Toplum, kendini iyi hissettiren, iyi şeylere destek olduğu duygusunu veren markalara yönelir. Domestos bu alanda okulları tercih ederek çocukların temiz ve sağlıklı alanlarda eğitim görmesine destek olarak, çocuklarda da temizlik bilinci oluşmasına katkı sağlamaktadır. Velilerde çocuklarının hijyenik ortamlarda bulunmasının iç rahatlığını yaşamasını sağlamaktadır. Bu noktada güven ve destek almaktadir.

Sonuç olarak bakıldığı zaman sosyal sorumluluk projeleri hem markanın hem de toplumun ihtiyaçlarını karşılamaya yönelik yapılan çalışmaları kapsamaktadır. Markalar toplum tarafindan benimsenmek, kabul görmek, markanın farkındalığını ve prestijini kaliteli bir noktaya getirmek için sosyal sorumluluk çalışmalarını halkla ilişkiler faaliyetleri kapsamında gerçekleştirir. Günümüzde markalar için bu tür çalışmalar gereklilik haline gelmiştir. Elde edilen verilerden de yola çıkarak söylemek gerekirse tüketici toplum, sosyal sorumluluk projelerine sicak bakmakta, sosyal sorumluluk projelerinin gerekliliğini savunmaktadır. Marka imajı ve sosyal sorumluluk çalışmaları yan yana tutulmakta ve memnuniyetle eş değer olarak görülmektedir. Marka imajının oluşması aynı zamanda marka değerinin de yükselmesine eşittir. Tüketici toplum, toplumsal değer ve duygularını doyurmayan markaları tercihlerinden elemede çekince duymamaktadır. Bir markanın sosyal sorumluluk çalışması yapması, aynı zamanda bu markanın pazar payında artış göstermesinde, diğer markalar arasından sıyrılmasına önemli bir etkendir. Markalar artık ürünlerinden çok, marka isimlerini tüketiciye sunmaktadır. Bir tüketici bir alışveriş merkezine, markete gittiği zaman ürünleri tercih ederken, ürünün markasının yapmış olduğu sosyal sorumluluk çalışmalarından hatırlayarak ürüne ve markaya karşı samimiyet duyar ve o markayı tercihlerinde ilk sıraya koyar. Bu da marka için tüketicide sahip olduğu marka farkındalığını ve marka sadakatini arttırmada etkilidir. $\mathrm{Bu}$ detaylara bakıldığı zaman marka sosyal sorumluluk çalışmaları, marka imajının ve itibarının yaratıcısıdır ve iyi hissettiren markalar bağımlılık yapar.

$\mathrm{Bu}$ çalışma ankete katılan 150 kişilik çalışma grubu ile sınırlıdır. $\mathrm{Bu}$ nedenle elde edilen veriler, çalışmanın sınırlılıkları kapsamında değerlendirilmiştir. Sosyal sorumluluk projelerinin markanın imaj ve itibarına nasıl etki ettiğini ortaya koymak amaciyla daha geniş örneklem gruplarında ve farklı markaların imajlarına ilişkin tüketici algısını belirlemeye yönelik karşılaştırmalı çalışmalar yapmak yararlı olacaktır.

\section{Kaynakça}

Brüggenwirth, B. (2006). "The CSR Brand Positioning Grid". In Jonker J., de Witte M. (Ed.). Management Models for Corporate Social Responsibility. (s.140146). Springer, Berlin, Heidelberg.

Clark, C. E. (2000). Differences Between Public Relations and Corporate Social Responsibility: An Analysis. Public Relations Review, 26(3), 363-380.

Capriotti, P. ve Moreno, A. (2006). Corporate Citizenship and Public Relations: The Importance and Interactivity of Social Responsibility Issues on Corporate Websites. Public Relations Review, 33, 84-91.

Cutlip, S. M., Center, A. H., ve Broom, G. M. (1994). EffectivePpublic Relations (7th ed.), Englewood Cliffs, NJ: Prentice-Hall.

Dozier, D. M. (1990). The Innovation of Research in Public Relations Practice: Review of a Program of Studies. Public Relations Research Annual, 2, 3-28.

Golob, Ursa ve Bartlett, J. L. (2007). Communicating About Corporate Social Responsibility: A Comparative Study of CSR reporting in Australia and Slovenia. Public Relations Review. 33(1), s. 1-9.

Goodwin, F. W. ve Bartlett, J. L. (2008). Public Relations and Corporate Social Responsibility (CSR): A Review of The Literatüre. Public Relations and CSR Review, 1-27. QUT Digital Repository:http://eprints.qut.edu.au/, Erişim Tarihi: 15.07.2018.

Grunig, J.E. (2001). Two Way Symmetrical Public Relations: Past, Present and Future. In R.L. Heath (Ed.). Handbook of Public Relations (pp. 11-30). Thousand Oaks, CA: Sage.

Gürbüz, S ve Şahin, F. (2016). Sosyal Bilimlerde Araştırma Yöntemleri. Ankara: Seçkin Yayınları.

Kirat, M. (2015). Corporate Social Responsibility In the Oil and Gas Industry In Qatar Perceptions and Practices. Public Relations Review, 41(4), 438-446.

Kotler, P., ve Lee N., (2005). Corporate Social Responsibility: Doing the Good for Your Company and Your Cause. Canada, John Wiley\&Sons.

Okullara Domestos Bağışı. http://www.domestoshijyenprojesi.com (Erişim Tarihi: 17.09.2018).

Özdemir, H. (2009). Kurumsal Sosyal Sorumluluğun Marka İmajına Etkisi. İstanbul Ticaret Üniversitesi Sosyal Bilimler Dergisi, 8(15), 57-72.

Vallaster, C., Lindgreen, A. ve Maon, F. (2012). Strategically Leveraging Corporate Social Responsibility: A Corporate Branding Perspective. California Management Review. University of California Press, 54(3), 34-60. 